Water quality is an important factor when

Monthly Levels and Criteria

Considerations of Nutrient, pH,

Alkalinity, and Ionic Variables in

Runoff Containment Basins in

Ornamental Plant Nurseries

\author{
Warren E. Copes ${ }^{1}$ \\ Thad Cochran Southern Horticultural Laboratory, United States Department \\ of Agriculture, Agricultural Research Service, 810 Highway 26 West, \\ Poplarville, MS 39470
}

Andrew Ristvey

Wye Research and Education Center, University of Maryland Extension, 124 Wye Narrows Drive, Queenstown, MD 21658

Patricia A. Richardson

Hampton Roads Agricultural Research and Extension Center, Virginia Polytechnic Institute and State University, 1444 Diamond Springs Road, Virginia Beach, VA 23455

Bruk E. Belayneh

Department of Plant Science and Landscape Architecture, University of Maryland, 2120 Plant Sciences Building, College Park, MD 20742

\section{Haibo Zhang}

Hampton Roads Agricultural Research and Extension Center, Virginia Polytechnic Institute and State University, 1444 Diamond Springs Road, Virginia Beach, VA 23455

\section{John Lea-Cox}

Department of Plant Science and Landscape Architecture, University of Maryland, 2120 Plant Sciences Building, College Park, MD 20742

\section{Chuanxue Hong}

Hampton Roads Agricultural Research and Extension Center, Virginia Polytechnic Institute and State University, 1444 Diamond Springs Road, Virginia Beach, VA 23455

Additional index words. recycling pond, nutrient analysis, nitrogen, phosphorus, electrical conductivity

\begin{abstract}
Triplicate water samples were collected monthly from nine waterways [eight runoff containment basins (RCBs) and one stream] on four commercial ornamental plant nurseries from February to July, and from one RCB and nursery from April to October. Four RCBs, one per nursery, were actively used as an irrigation water source. Analysis was done for 18 water quality variables, including ammonium-nitrogen $\left(\mathrm{NH}_{4}{ }^{+}-\mathrm{N}\right)$, nitratenitrogen $\left(\mathrm{NO}_{3}{ }^{-}-\mathrm{N}\right)$, ortho phosphate-phosphorus $\left(\mathrm{PO}_{4}-\mathrm{P}\right)$, total-phosphorus (T-P), potassium (K), calcium (Ca), magnesium (Mg), sulfur (S), aluminum (Al), boron (B), copper (Cu), iron (Fe), manganese (Mn), zinc ( $\mathrm{Zn}), \mathrm{pH}$, total alkalinity (T-Alk), electrical conductivity (EC), and sodium (Na). The degree and rate of monthly change varied considerably between RCBs. Macronutrients generally increased at most nurseries in 1-2 months after fertilizer application particularly in three RCBs (MD21, VA11, and VA12), with levels of $\mathrm{N}$ - and $\mathrm{P}$ forms exceeding preferred criteria for irrigation water by June and July in VA11 and VA12. Micronutrients fluctuated less but did vary per RCB with the most monthly change occurring in MD21. Even though pH fluctuated, $\mathrm{pH}$ tended to remain alkaline or neutral to acidic respective of the RCB during the entire sample period. T-Alk tended to increase over the summer. EC primarily fluctuated in RCBs with high macronutrient levels. Although levels of $\mathrm{N}$ - and $\mathbf{P}$ forms were mostly suitable by irrigation water criteria, they were frequently above U.S. Environmental Protection Agency (USEPA) nutrient criteria for promoting healthy water environments of lakes and reservoirs, and are discussed.
\end{abstract}

considering withdrawal of irrigation water from runoff containment basins (RCBs) in ornamental plant nurseries. A water quality standard defines the water quality goals needed to meet the designated use(s) of a water body (USEPA, 2014). In commercial ornamental nursery operations, RCBs are built for the purpose of capturing water runoff, which can contain nutrients from fertilizers and other chemicals applied to plants. RCBs also expand water availability by capturing rainwater, extend water availability by capturing container leachates and ground interception of irrigation water, and prevent runoff that would otherwise contribute to off-site pollution. However, concern exists over the suitability of water quality drawn from RCBs as well as the potential for dispersing plant pathogens. Water quality can refer to many properties of water. Water quality can be described by the status of water $\mathrm{pH}$, alkalinity, nutrient content, various ionic properties, oxygen demand, presence of residual pesticides, soluble and suspended sediment, and algal populations (Chen and Beeson, 2004; Chen et al., 2003; Hem, 1985; Majsztrik et al., 2011; Meador et al., 2012; Moss et al., 2003; Obreza et al., 2011; Warsaw et al., 2009b; Wilson et al., 2010).

Nitrogen, phosphorus, EC, $\mathrm{pH}$, and alkalinity levels are commonly considered basic measures of water quality, whereas the other variables may or may not be reported (Argo and Biernbaum, 1996; Dole et al., 2011; Zhang et al., 2015a). Many informational and Cooperative Extension documents (not cited) provide partial to comprehensive lists of preferred ranges for nutrients, $\mathrm{pH}$, and ionic properties of water quality levels that are desirable for ornamental plant production. These ranges tend to be similar for greenhouse and nursery crops (Dole et al., 2011; Robbins, 2010). Argo and Biernbaum (1996) showed that a significant percentage of water sources used for greenhouse irrigation water in 11 states of the United States exceeded preferred ranges but no correlation was made to plant quality. Chen et al. (2003) recorded high $\mathrm{pH}$ levels but low to moderate alkalinity and EC levels in irrigation water from an RCB. Monthly $\mathrm{pH}$ levels were at or slightly above 9 throughout the year, whereas low to moderate EC levels fluctuated, depending on rainfall, with no detrimental effect on plant growth of foliage and bedding plants (Chen et al., 2003). They theorized that even though $\mathrm{pH}$ levels of the RCB were high, low water alkalinity allowed water $\mathrm{pH}$ to not influence the $\mathrm{pH}$ of plant's growing media, which had a high buffering capacity (Chen and Beeson, 2004). Meador et al. (2012) sampled irrigation water from multiple water sources used by 24 greenhouse and nursery operations across the United States and found that chemical water quality variables of alkalinity and EC were generally suitable for irrigation sources, whereas average ultraviolet transmission and biological water quality was lower and $\mathrm{pH}$ higher than preferred levels. Copes et al. (2017) found water 
quality parameter values mostly present at low to preferred levels in $25 \mathrm{RCBs}$ in the Mid-Atlantic and southeastern United States. Water was being actively used for irrigation without any obvious plant health problems observed by nursery production managers, despite macronutrients being higher than preferred for several months in three RCBs and water $\mathrm{pH}$ being alkaline $(>8)$ in several RCBs (Copes et al., 2017).

Although nutrient and ionic water levels for many RCBs have been described as suitable for health of ornamental plant production, algal blooms are common in RCBs during summer months and perceived as signs of an unhealthy waterway. Different water quality standards have been developed to address the problem of eutrophication in waterways for the purpose of maintaining natural aquatic habitats, which includes minimizing occurrence of algal blooms (Chambers et al., 2012; Evans-White et al., 2013; USEPA, 2000, 2001). Since 1998, the USEPA has been actively defining water quality criteria that contribute to healthy biological conditions in different types of water bodies, although none have been developed specifically for addressing agricultural watersheds (Chambers et al., 2012; Evans-White et al., 2013; USEPA, 2014). USEPA-generated ecoregional nutrient criteria provide regionally relevant baseline criteria to be used by States and authorized Tribes for developing water quality standards that address eutrophication in waterways (Evans-White et al., 2013; USEPA, 2000, 2001). Florida, as an example, reassessed USEPA standards and set $\mathrm{NO}_{3}{ }^{-}-\mathrm{N}$ standards at $1.9 \mathrm{mg} \cdot \mathrm{L}^{-1}$ to inhibit excessive plant and algal growth in aquatic ecosystems (Obreza et al., 2011). These standards are stricter than the $10 \mathrm{mg} \cdot \mathrm{L}^{-1} \mathrm{NO}_{3}{ }^{-} \mathrm{N}$ standard used for ornamental plant production and for drinking water, and demonstrate how the relevancy

Received for publication 5 Sept. 2017. Accepted for publication 21 Jan. 2018.

This research was supported in part by the USDA National Institute of Food and Agriculture Specialty Crop Research Initiative (agreement number 2010-51181-21140); the U.S. Department of Agriculture, Agricultural Research Service, Thad Cochran Southern Horticultural Laboratory, Southern Horticultural Research Unit project number 6404-21430-001-00D; and Virginia Agricultural Experiment Station.

We thank collaborating growers for providing access to the study reservoirs and on-site assistance.

C.H. contributed to the study's conception, and manuscript reviewing and editing. W.E.C. performed data acquisition in the reservoir in Mississippi and contributed to data analysis, manuscript drafting, and revising. P.A.R. performed data acquisition in reservoirs in Virginia and edited the manuscript. B.E.B. and A.R. collected data in reservoirs in Maryland and edited the manuscript. H.Z. and J.L-C. contributed to manuscript reviewing and editing.

${ }^{1}$ Corresponding author. E-mail: warren.copes@ars. usda.gov. of water quality criteria depends on usage purposes.

ECs measured from container leachates have been correlated with high $\mathrm{N}$ levels because of controlled release fertilizers (CRFs) (Bilderback et al., 1999). This has been further corroborated by levels found in irrigation runoff. Yeager et al. (1993) found moderately high $\mathrm{NO}_{3}{ }^{-}-\mathrm{N}$ concentrations up to $33 \mathrm{mg} \cdot \mathrm{L}^{-1}$ in irrigation runoff. Wilson et al. (2010) measured moderate to high levels of $\mathrm{NO}_{3}{ }^{-}-\mathrm{N}$ concentrations, from 0.7 to 386.4 $\mathrm{mg} \cdot \mathrm{L}^{-1}$, in runoff on nurseries. These levels would be diluted on flowing into an RCB. Nitrogen and phosphorus have been measured at relatively low levels in RCBs in several studies (Chen et al., 2003; Chiandet and Xenopoulos, 2016; Copes et al., 2017).
Chen et al. (2003) measured low levels of $\mathrm{NO}_{3}{ }^{-}-\mathrm{N}\left(0.04 \mathrm{mg} \cdot \mathrm{L}^{-1}\right)$ and $\mathrm{T}-\mathrm{P}\left(0.87 \mathrm{mg} \cdot \mathrm{L}^{-1}\right)$ in an RCB. Copes et al. (2017) found that water quality parameter values sampled from 25 waterways in Alabama (AL), Louisiana (LA), Maryland (MD), Mississippi (MS), and Virginia (VA) were mostly present at low to preferred levels for irrigation water, with levels of $0.05-13.88 \mathrm{mg} \mathrm{NO}_{3}-\mathrm{N} / \mathrm{L}$ and 0.10-2.29 mg T-P/L.

RCBs are relatively small bodies of water that range in size and depth of $\approx 0.8-8$ ha and $0.75-5 \mathrm{~m}$, respectively. Despite their small size, water dynamics can result in differences between horizontal, vertical, and temporal measurements. Subsurface water quality at the inflow inlet of RCBs can have a higher temperature (as much as $2.8^{\circ} \mathrm{C}$ ), lower $\mathrm{pH}$

Table 1. Months when top-dressed or soluble fertilizers were applied to container-grown plants at ornamental plant nurseries.

\begin{tabular}{|c|c|c|c|c|c|c|c|}
\hline \multirow[b]{2}{*}{ Nursery } & \multirow{2}{*}{$\begin{array}{l}\text { Incorporated } \\
\text { fertilizer }\end{array}$} & \multicolumn{6}{|c|}{ Month top-dressed fertilizer applied } \\
\hline & & January & February & March & April & May & June \\
\hline$\overline{\mathrm{MD}^{\mathrm{z}}}$ & Yes & & & CRF & & & \\
\hline $\mathrm{MD}^{\mathrm{y}}$ & Yes & LSF & LSF & CRF, LSF & LSF & LSF & LSF \\
\hline$M S 1^{x}$ & Yes & & CRF & CRF & & & \\
\hline $\mathrm{VA} 1^{\mathrm{w}}$ & Yes & $\mathrm{CRF}$ & & CRF, LSF & LSF & LSF & CRF, LSF \\
\hline $\mathrm{VA} 2^{\mathrm{v}}$ & No & & $\mathrm{CRF}$ & CRF, LSF & LSF & LSF & \\
\hline
\end{tabular}

${ }^{\mathrm{z}}$ Top-dressed application of Harrell's 15-9-12, 8-9 months.

${ }^{\mathrm{y}} \mathrm{CRF}$ applied to nursery plants possibly in March and liquid soluble fertilizer (LSF) applied to greenhouse plants all year. Detailed information of fertilizer mixture and month of application is not available because ownership changed since 2013.

${ }^{\mathrm{x}}$ Urea formaldehyde and micronutrient incorporated in bark media. Top-dressed application of Harrell's 18-7-9 CRF applied nursery wide from February to March. Propagation liners fertilized with Harrell's 19-6-12 CRF from March to June.

${ }^{\text {w} H a r r e l l ' s ~ 18-4-8 ~ C R F ~ i n c o r p o r a t e d ~ a n d ~ a p p l i e d ~ a s ~ t o p-d r e s s i n g ~ t o ~ s p e c i f i c ~ c r o p s ~ i n ~ J a n u a r y ~ o r ~ M a r c h ~ a n d ~}$ as needed in June. Liquid fertilizer $(10-4-6)$ applied as needed based on pour-through electrical conductivity measurements.

vTop-dressed application of Harrell's 17-3-7 CRF in February and March. Liquid fertilizer applied as needed to annuals.

$\mathrm{CRF}=$ controlled release fertilizer; $\mathrm{MD}=$ Maryland; $\mathrm{MS}=$ Mississippi; $\mathrm{VA}=$ Virginia .

Table 2. Criteria ranges for the "Irrigation for Plant Production Water Quality" (IPP) criteria of preferred levels for irrigation water used in nursery production of ornamental plants (Robbins, 2010) and for "Ecoregion IX Lake and Reservoir Ambient Water Quality" (E9LR) criteria (USEPA, 2000) and "Ecoregion XIV Lake and Reservoir Ambient Water Quality" (E14LR) criteria (USEPA, 2001).

\begin{tabular}{|c|c|c|c|}
\hline Water quality variables ${ }^{2}$ & IPP criteria range & Water quality variables & IPP criteria range \\
\hline Macronutrients & & Micronutrients & \\
\hline $\mathrm{NH}_{4}^{+}-\mathrm{N}, \mathrm{mg} \cdot \mathrm{L}^{-1}$ & $\mathrm{NA}^{\mathrm{y}}$ & $\mathrm{Al}, \mathrm{mg} \cdot \mathrm{L}^{-1}$ & $0-5$ \\
\hline $\mathrm{NO}_{3}{ }^{-}-\mathrm{N}, \mathrm{mg} \cdot \mathrm{L}^{-1}$ & $0-10$ & $\mathrm{~B}, \mathrm{mg} \cdot \mathrm{L}^{-1}$ & $0.2-0.5$ \\
\hline $\mathrm{PO}_{4}-\mathrm{P}, \mathrm{mg} \cdot \mathrm{L}^{-1}$ & NA & $\mathrm{Cu}, \mathrm{mg} \cdot \mathrm{L}^{-1}$ & $0.05-0.15$ \\
\hline $\mathrm{T}-\mathrm{P}, \mathrm{mg} \cdot \mathrm{L}^{-1}$ & $0-1$ & $\mathrm{Fe}, \mathrm{mg} \cdot \mathrm{L}^{-1}$ & $1-3$ \\
\hline $\mathrm{K}, \mathrm{mg} \cdot \mathrm{L}^{-1}$ & $1-10$ & $\mathrm{Mn}, \mathrm{mg} \cdot \mathrm{L}^{-1}$ & $0.2-1.0$ \\
\hline $\mathrm{Ca}, \mathrm{mg} \cdot \mathrm{L}^{-1}$ & $40-100$ & $\mathrm{Zn}, \mathrm{mg} \cdot \mathrm{L}^{-1}$ & $0.0-0.2$ \\
\hline $\mathrm{Mg}, \mathrm{mg} \cdot \mathrm{L}^{-1}$ & $5-25$ & Ionic properties & \\
\hline \multirow[t]{4}{*}{$\mathrm{S}, \mathrm{mg} \cdot \mathrm{L}^{-1}$} & $25-200$ & $\mathrm{pH}$, units & $5.2-6.8$ \\
\hline & & $\mathrm{T}$-Alk, mg. $\mathrm{L}^{-1}$ & $0-140$ \\
\hline & & $\mathrm{EC}, \mathrm{mmho} \cdot \mathrm{cm}^{-1}$ & $0.0-0.3$ \\
\hline & & $\mathrm{Na}, \mathrm{mg} \cdot \mathrm{L}^{-1}$ & $0-30$ \\
\hline Water quality variables ${ }^{2}$ & $\begin{array}{l}\text { E9LR 25th percentile } \\
\text { value (and range) }\end{array}$ & Water quality variables & $\begin{array}{l}\text { E14LR 25th percentile } \\
\text { value (and range) }\end{array}$ \\
\hline $\mathrm{T}-\mathrm{N},{ }^{\mathrm{x}} \mathrm{mg} \cdot \mathrm{L}^{-1}$ & $0.36(0.30-0.96)$ & $\mathrm{T}-\mathrm{N}, \mathrm{mg} \cdot \mathrm{L}^{-1}$ & $0.32(0.32-0.41)$ \\
\hline $\mathrm{T}-\mathrm{P}, \mathrm{mg} \cdot \mathrm{L}^{-1}$ & $0.020(0.010-0.062)$ & $\mathrm{T}-\mathrm{P}, \mathrm{mg} \cdot \mathrm{L}^{-1}$ & $0.008(0.008-0.020)$ \\
\hline
\end{tabular}

${ }^{\mathrm{z}}$ Water analysis consisted of the determination of ammonium-nitrogen $\left(\mathrm{NH}_{4}{ }^{+}-\mathrm{N}\right)$, nitrate-nitrogen $\left(\mathrm{NO}_{3}{ }^{-}-\mathrm{N}\right)$, ortho phosphate-phosphorus $\left(\mathrm{PO}_{4}-\mathrm{P}\right)$, total-phosphorus $(\mathrm{T}-\mathrm{P})$, potassium $(\mathrm{K})$, calcium $(\mathrm{Ca})$, magnesium $(\mathrm{Mg})$, sulfur $(\mathrm{S})$, aluminum $(\mathrm{Al})$, boron $(\mathrm{B})$, copper $(\mathrm{Cu})$, iron $(\mathrm{Fe})$, manganese $(\mathrm{Mn})$, zinc $(\mathrm{Zn}), \mathrm{pH}$, total alkalinity (T-Alk), electrical conductivity (EC), and sodium (Na) performed by the University of Delaware Soils and Plant Analysis Laboratory, Newark, DE.

${ }^{\mathrm{y}}$ Range not available in Robbins (2010).

${ }^{\mathrm{x}}$ Because $\mathrm{T}-\mathrm{N}$ was not determined from the water samples, $\mathrm{NH}_{4}{ }^{+}-\mathrm{N}$ and $\mathrm{NO}_{3}{ }^{-}-\mathrm{N}$ levels were added to produce an $\approx \mathrm{T}-\mathrm{N}$ for comparison with E9LR and E14LR criteria.

$\mathrm{T}-\mathrm{N}=$ total-nitrogen 
(as much as two units), lower dissolved oxygen (DO, as much as $2.8 \mathrm{mg} \cdot \mathrm{L}^{-1}$ ), and higher oxidative-reduction potential (ORP, as much as $290 \mathrm{mV}$ ) than in the middle of the RCB (Zhang et al., 2015b). In addition, pronounced vertical differences can occur from about April to October when thermal stratifications form. Zhang et al. (2015a, 2016) characterized a monomictic thermal stratification with higher temperatures in the upper vertical water layers of RCBs in MD and VA. During the stratification period, water forms distinct horizontal water layers that do not mix vertically (McEnroe et al., 2013; Song et al., 2013). This was characterized by an upper vertical water layer with a higher temperature (as much as $21.5^{\circ} \mathrm{C}$ ), higher $\mathrm{pH}$ (as much as 4.2 units), higher DO (as much as $13.0 \mathrm{mg} \cdot \mathrm{L}^{-1}$ ), higher ORP (as much as $505.7 \mathrm{mV}$ ), and lower EC (as much as $0.9 \mathrm{dS} \cdot \mathrm{m}^{-1}$ ) than the bottom vertical water layer (Zhang et al., 2015a, 2016). Under stratification conditions, algal communities, as measured by chlorophyll $\alpha$, were found to be densest in the middle vertical layer of the RCB (Zhang et al., 2015a). Heavy rainfall can cause dilution of soluble nutrients but an increase in particulate and suspended matter (Havens et al., 2007; Stutter et al., 2008; Zhu et al., 2007). Although wind can cause water movement and stirring of particulate and suspended matter (Wang et al., 2011; Zhu et al., 2007), Zhang et al. (2016) found minimal impact from wind in RCBs on ornamental plant nurseries. It is evident that water quality is not equal in all parts of an RCB and across all seasons.
The objective of this study was to evaluate patterns of nutrient, $\mathrm{pH}$, and ionic water quality variables in multiple RCBs that are used to contain runoff or as sources of irrigation water in commercial ornamental plant nurseries in the Mid-Atlantic and southeastern United States in 2013 over spring and summer months when plants are fertilized. Does monthly water quality from these RCBs stay below preferred criteria for irrigation water used for ornamental plant production and below the even stricter USEPA levels for open water habitats or above these criteria?

\section{Materials and Methods}

Monthly temporal assessments. Samples were collected from water sources in MD, $\mathrm{MS}$, and VA. The 10 water sources were

Table 3. Significance of monthly differences in water quality variables, and degree and trend of change relative to preferred levels in irrigation water from February to July per eight runoff containment basins (RCBs) and one stream (VA10), and one RCB (MS11) sampled from April to October.

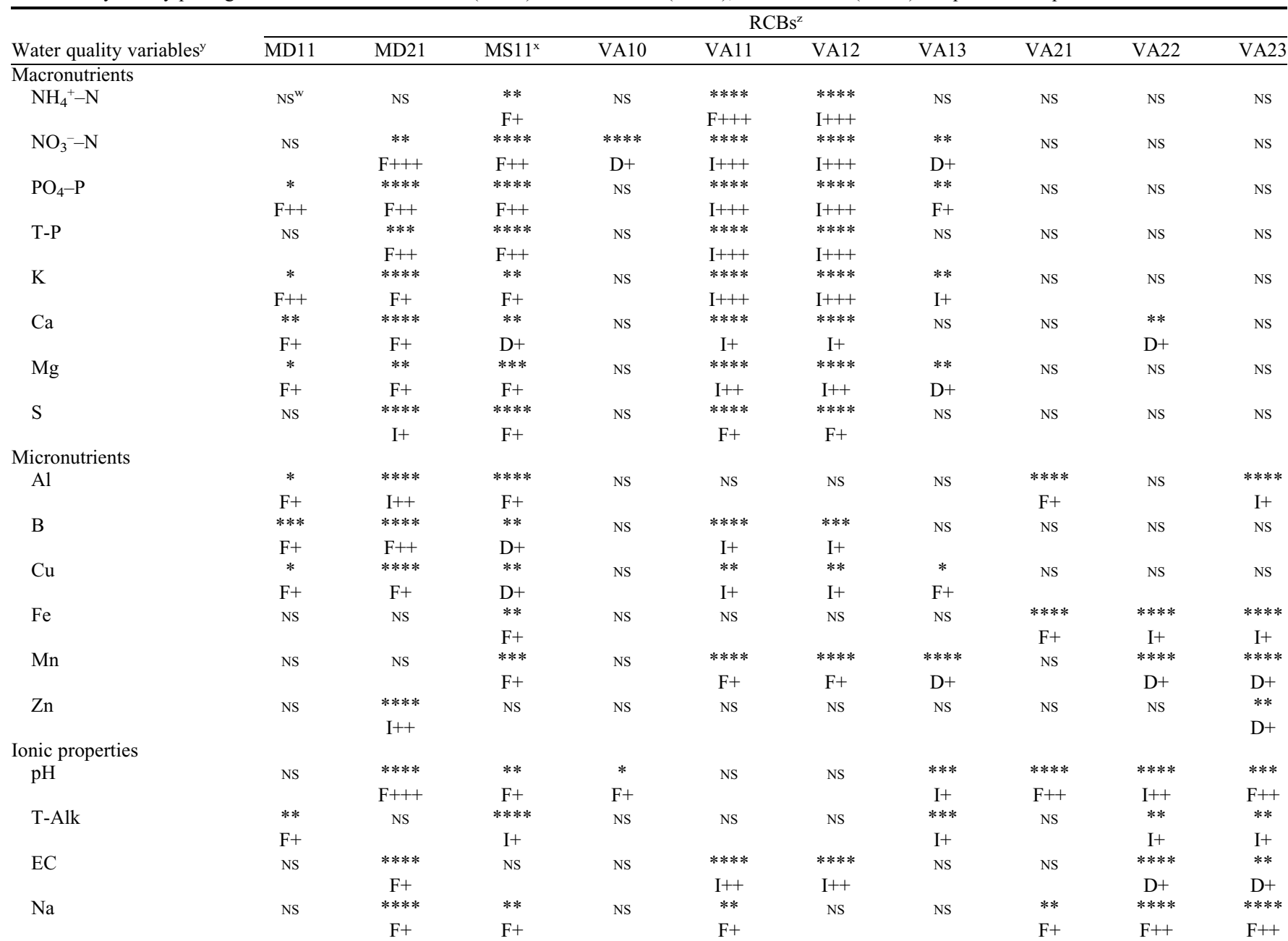

${ }^{\mathrm{z}}$ The 10 water sources were labeled by the state abbreviation followed by sequential numbering of nurseries sampled in that state and number of RCBs sampled at a nursery, with the stream receiving a zero designation.

${ }^{\mathrm{y}}$ Water analysis consisted of the determination of ammonium-nitrogen $\left(\mathrm{NH}_{4}{ }^{+}-\mathrm{N}\right)$, nitrate-nitrogen $\left(\mathrm{NO}_{3}{ }^{-}-\mathrm{N}\right)$, ortho phosphate-phosphorus $\left(\mathrm{PO}{ }_{4}-\mathrm{P}\right)$, totalphosphorus (T-P), potassium (K), calcium $(\mathrm{Ca})$, magnesium $(\mathrm{Mg})$, sulfur $(\mathrm{S})$, aluminum $(\mathrm{Al})$, boron $(\mathrm{B})$, copper $(\mathrm{Cu})$, iron $(\mathrm{Fe})$, manganese $(\mathrm{Mn})$, zinc $(\mathrm{Zn})$, pH, total alkalinity (T-Alk), electrical conductivity (EC), and sodium (Na) performed by the University of Delaware Soils and Plant Analysis Laboratory, Newark, DE. ${ }^{\mathrm{x}}$ MS11 was sampled from April to October; therefore, the dataset was analyzed separately, although results are shown with the larger dataset.

${ }^{w}$ Probability of significance is listed within non-over lapping discreet categories: ${ }^{\text {ss }} P>0.1, * P=0.1, * * P=0.05, * * * P=0.01$, and $* * * * P<0.001$. Analysis of variance was performed using the MIXED procedure for repeated measures (SAS 9.4). The SLICE function was used to compare means between months within a nursery, and means separation was performed using Tukey's multiple comparison adjustment of least squares means. Letters indicate the general trend across months as decreasing (D), fluctuating between increasing and decreasing (F), and increasing (I) when variables were significant; and the relative degree of change as narrow $(+)$, moderate $(++)$, and wide $(+++)$ in reference to preferred levels for irrigation water (Robbins, 2010).

$\mathrm{MD}=$ Maryland; $\mathrm{NS}=$ nonsignificant; $\mathrm{MS}=$ Mississippi; $\mathrm{VA}=$ Virginia. 
labeled first by the state abbreviation, second by an arbitrary sequential numbering of the nurseries sampled within a state (1 or 2), and third by sequential numbering of RCBs (1-3) connected in series by overflow culverts, as follows: MD11, MD21, MS11, VA10, VA11, VA12, VA13, VA21, VA22, and VA23. MD11 and MD21 receive irrigation runoff directly from the production area and are direct sources for irrigation water. MS11, VA11, and VA21 receive irrigation runoff directly from the production area and indirectly serve as a source for irrigation water. VA12 and VA23 are direct sources for irrigation water and receive overflow second or third in series, respectively, from RCBs that directly receive runoff. VA13 and VA22 neither receive runoff directly nor serve as direct sources of irrigation water. VA22 is connected directly to other RCBs that serve those functions. VA13 only receives overflow occasionally when a trap door at one end of the culvert that is normally closed is manually opened. The stream (VA10) is a local natural water source that does not receive runoff from the nursery, thus used as a comparison with VA11, VA12, and VA13. Descriptions of MD and VA RCBs and stream have been previously published using the same label designation (Zhang et al., 2015a, 2015b, 2016). A description of MS11 was previously described in Copes et al. (2015) where it was labeled M2.

Fertilizer was incorporated into container media at all nurseries, except for VA2. Fertilizer was applied as a top-dressing of CRF or liquid soluble feed to different plant selections in the production area from January to June but mostly in March (Table 1).

The nine RCBs and one stream (VA10) in $\mathrm{MD}$, MS, and VA were sampled monthly from February to July in 2013; however, water samples were not collected in every month from all 10 water sources, resulting in an incomplete design. MS11 was sampled for three additional months from August to October in 2013, thus analyzed separately from the other RCBs. A single set of water samples was collected monthly between 11:00 AM and 1:00 PM at $\approx 10-30 \mathrm{~cm}$ below the RCB surface. Every sampling set consisted of three 1 -L subsamples taken $\approx 1 \mathrm{~m}$ apart from each other in a triangular pattern around a data sonde buoy located about in the center of the RCB. Types of collection bottles and pretreatments are described in Copes et al. (2017). Water analysis of monthly samples consisted of the determination of $\mathrm{NH}_{4}{ }^{+}-\mathrm{N}, \mathrm{NO}_{3}{ }^{-}-\mathrm{N}, \mathrm{PO}_{4}-\mathrm{P}, \mathrm{T}-\mathrm{P}, \mathrm{K}, \mathrm{Ca}, \mathrm{Mg}, \mathrm{S}$, $\mathrm{Al}, \mathrm{B}, \mathrm{Cu}, \mathrm{Fe}, \mathrm{Mn}, \mathrm{Zn}, \mathrm{pH}, \mathrm{T}-\mathrm{Alk}, \mathrm{EC}$, and $\mathrm{Na}$ and were performed by the University of Delaware Soils and Plant Analysis Laboratory, Newark, DE.

From this point, two criteria will be used to evaluate potential health of the RCBs and will be referred to as "Irrigation for Plant Production Water Quality" criteria (IPP criteria; Table 2; Robbins, 2010), and "Ecoregion IX Lake and Reservoir Ambient Water Quality" criteria (E9LR criteria; USEPA, 2000) or "Ecoregion XIV Lake and Reservoir
Ambient Water Quality" criteria (E14LR criteria; USEPA, 2001). Ecoregion IX is the southeastern temperate-forested plains and hills region from MS through Georgia up to MD where the nurseries MD2, MS1, and VA2 are located. Ecoregion XIV is the eastern coastal plain region from South Carolina through Long Island, NY, where the nurseries MD1 and VA1 are located. The 25 th percentile value (and range) of level 3, aggregate nutrients for total-nitrogen (T-N), and T-P of ecoregion IX lakes and reservoirs (USEPA, 2000) and ecoregion XIV lakes and reservoirs (USEPA, 2001) are shown in Table 2. Nutrient levels above these criteria have been associated with the likelihood of an overgrowth of phytoplankton, diminished plant life diversity, and a decline in the balance of a healthy biological community. USEPA criteria are considerably lower than the preferred irrigation water quality ranges listed by Robbins (2010) but provide a baseline to consider feasibility of controlling algal blooms. Because T-N was not determined from the water samples, $\mathrm{NH}_{4}{ }^{+}-\mathrm{N}$ and $\mathrm{NO}_{3}{ }^{-}-\mathrm{N}$ levels were added to produce an $\approx \mathrm{T}-\mathrm{N}$ for comparison with E9LR and E14LR criteria.

Data analysis. Monthly temporal assessments were analyzed using the analysis of variance MIXED procedure for repeated measures (SAS 9.4). Repeated measures were monthly samples over spring and summer seasons per RCB ( $n=5$ or 6 , dependent

MD11

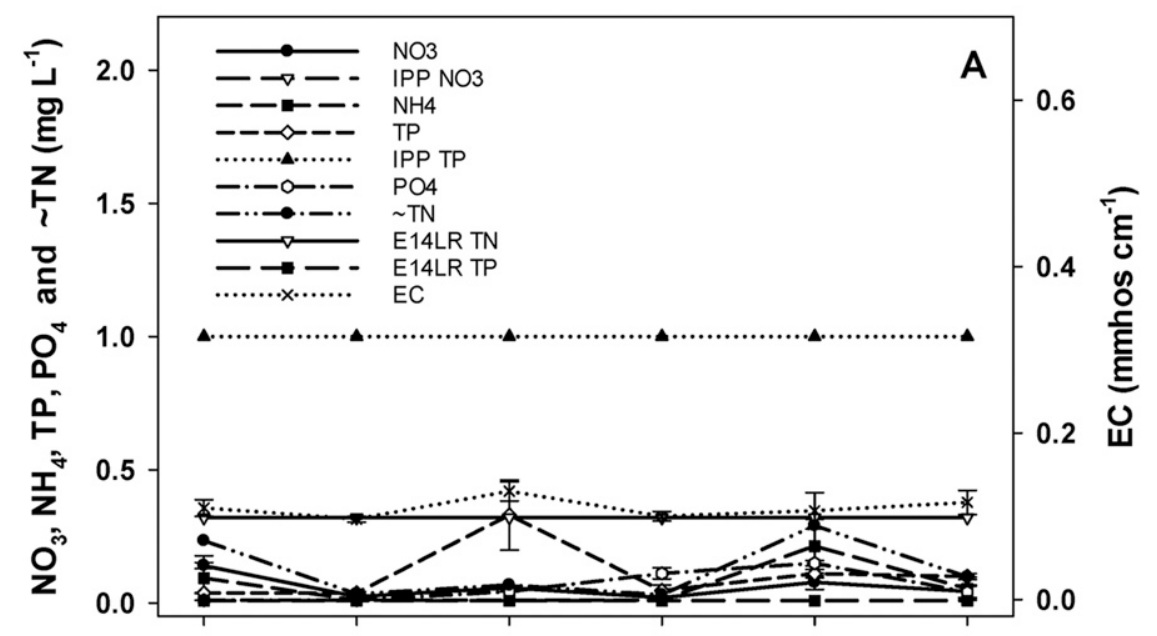

MD11

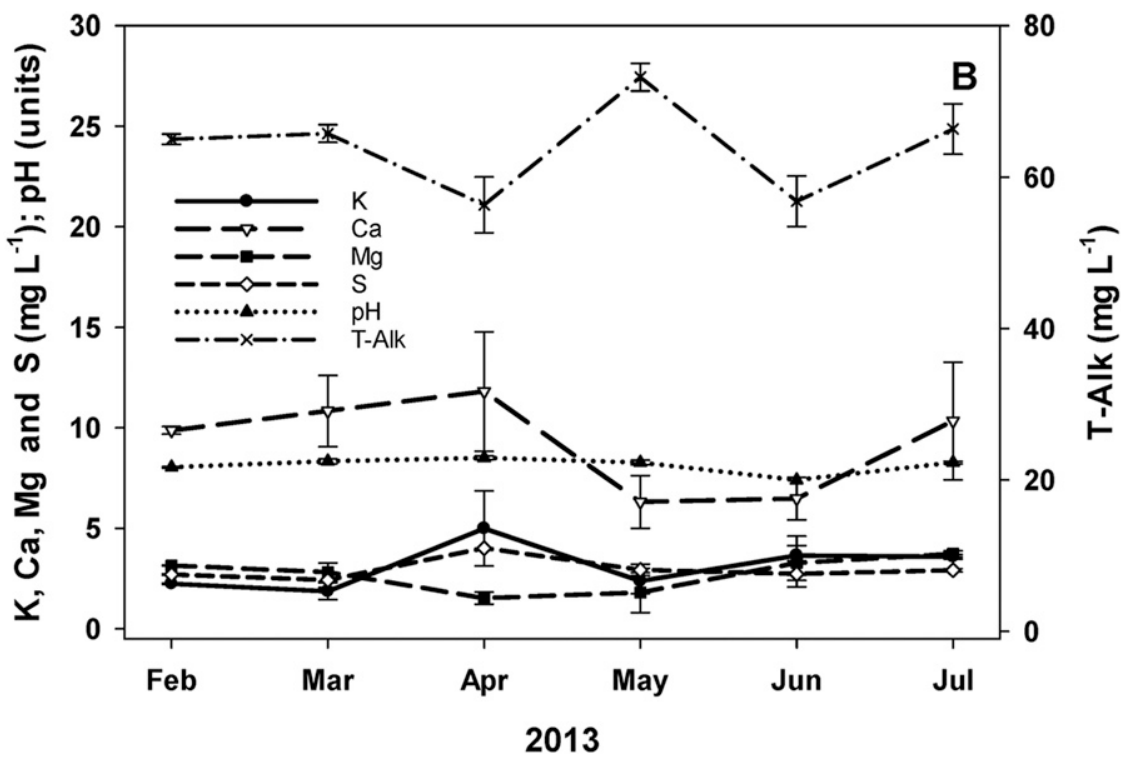

Fig. 1. Monthly mean levels $(n=6)$ for $(\mathbf{A})$ ammonium-nitrogen $\left(\mathrm{NH}_{4}{ }^{+}-\mathrm{N}\right)$, nitrate-nitrogen $\left(\mathrm{NO}_{3}{ }^{-}-\mathrm{N}\right)$,

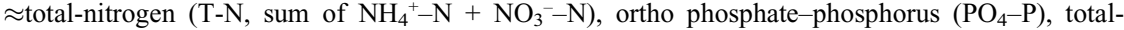
phosphorus (T-P), and electrical conductivity (EC), and the "Irrigation for Plant Production Water Quality" criteria (IPP $\mathrm{NO}_{3}{ }^{-}-\mathrm{N}=10 \mathrm{mg} \cdot \mathrm{L}^{-1}$ is higher than the $\mathrm{Y}$-axis range) and "Ecoregion XIV Lake and Reservoir Ambient Water Quality" (E14LR) criteria; and for (B) potassium (K), calcium (Ca), magnesium $(\mathrm{Mg})$, sulfur $(\mathrm{S}), \mathrm{pH}$, and total alkalinity (T-Alk) in a runoff containment basin in Maryland (MD11) in 2013. 
on the number of months sampled). Fixed factors were RCB, month, and their interactions, and the random variable was subsamples. A repeated measures covariant structure was individually determined for each of the 18 response variables in each analysis by evaluating treatment variances, mean patterns, and time period covariance structure. The SLICE function was used to compare means between times within a nursery and between nurseries within a time. The null hypothesis of all treatments being equal were tested using Tukey's multiple comparison adjustment of least squares means $(P=0.05)$. Because MS1 1 was sampled additional months than the other nurseries, data analysis was performed separately. For all other RCBs, months not sampled were treated as missing data.

\section{Results}

Significant differences occurred between at least 1 month for all RCBs $(P<0.0001)$ for all water quality variables; between at least one RCB for each month (at a $P<0.0001$ ) for most water quality variables, with different probabilities for $\mathrm{S}(P=0.0004), \mathrm{Al}$ $(P=0.0236), \mathrm{Zn}(P=0.0002), \mathrm{pH}(P=$ $0.0004)$, and T-Alk $(P=0.0112)$; and with significant interactions between RCB and month $(P<0.0001)$ for all water quality values except $\mathrm{Cu}(P=0.2524)$. The largest number of monthly differences between water quality values occurred in MD21, MS11, VA11, and VA12 (Table 3). The least number of monthly differences between water quality values occurred in VA10 and VA21 (Table 3). Because several tables and figures would be needed to display all monthly differences and interactions for each RCB, only the more pertinent and relevant differences will be shown. The main focus will be on significant changes over 5-6 months by RCB (Figs. 1-10). Interpretation of results in Figs. 1-10 requires looking at significance shown in Table 3 and checking preferred levels (Table 2) stated in Robbins (2010) to assess relevance of numerical changes because for some variables, the scale of the graphs magnify or minimize changes.

In MD11, a small synchronous increase occurred with $\mathrm{NO}_{3}{ }^{-}-\mathrm{N}$ and $\mathrm{EC}$ in April and small synchronous increases and decreases of $\mathrm{NH}_{4}{ }^{+}-\mathrm{N}$, T-P, and $\mathrm{PO}_{4}-\mathrm{P}$ levels occurred in June and July (Fig. 1A; Table 3). The $\approx \mathrm{T}-\mathrm{N}$ levels $\left(0.03-0.290 \mathrm{mg} \cdot \mathrm{L}^{-1}\right)$ were below those specified for the E14LR 25th percentile value for T-N during the entire sample period, thus well below IPP criteria (Table 2). T-P levels (0.037-0.110 $\left.\mathrm{mg} \cdot \mathrm{L}^{-1}\right)$ were above the E14LR 25th percentile value for T-P, but well below the IPP criteria during the entire sample period.

In MD21, synchronous increases for $\mathrm{NO}_{3}{ }^{-}-\mathrm{N}, \mathrm{NH}_{4}{ }^{+}-\mathrm{N}, \mathrm{T}-\mathrm{P}, \mathrm{PO}_{4}-\mathrm{P}$, and $\mathrm{EC}$ levels occurred in May and July (Fig. 2A; Table 3). No water samples were collected in April. The $\approx \mathrm{T}-\mathrm{N}$ levels $\left(0.353-1.830 \mathrm{mg} \cdot \mathrm{L}^{-1}\right)$ exceeded the E9LR 25th percentile value for $\mathrm{T}-\mathrm{N}$ levels in May and July only and were

MD21

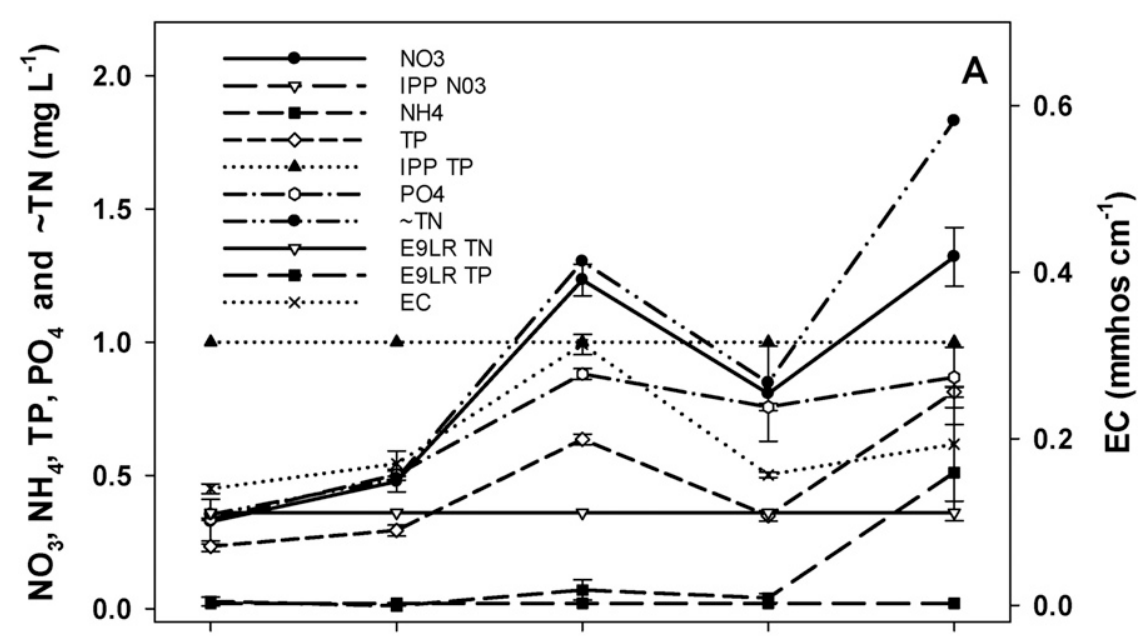

MD21

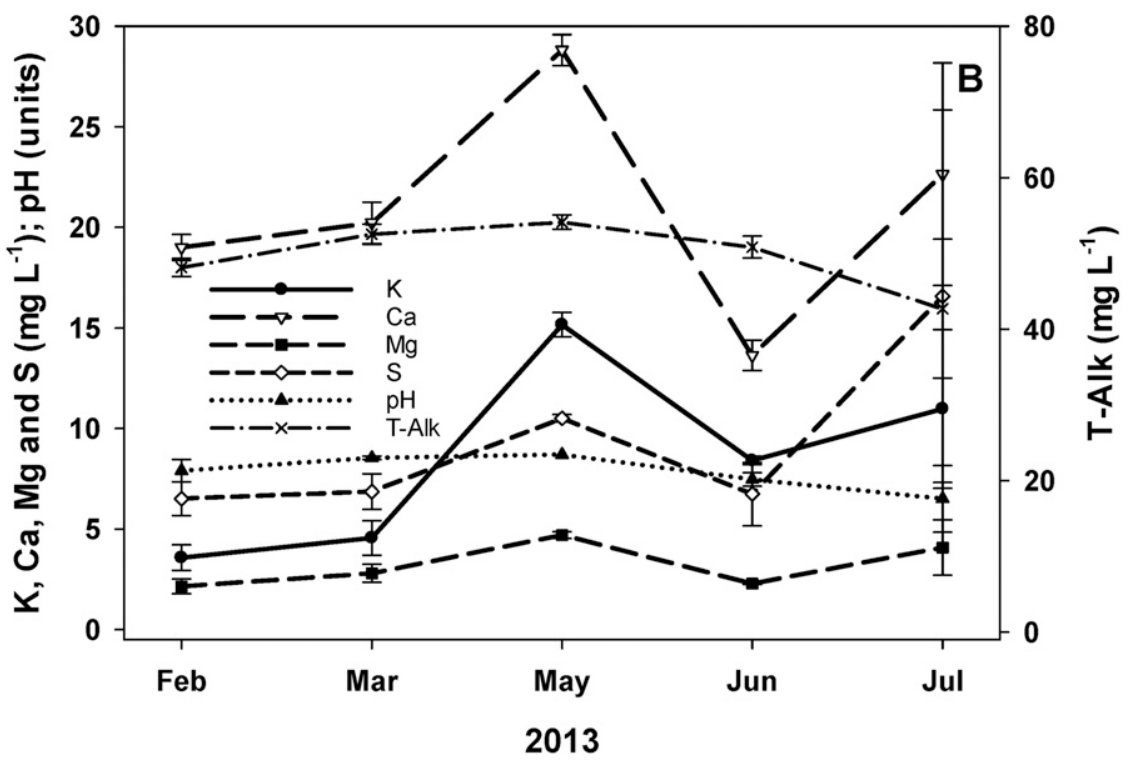

Fig. 2. Monthly mean levels $(n=5)$ of $(\mathbf{A})$ ammonium-nitrogen $\left(\mathrm{NH}_{4}{ }^{+}-\mathrm{N}\right)$, nitrate-nitrogen $\left(\mathrm{NO}_{3}{ }^{-}-\mathrm{N}\right)$, $\approx$ total-nitrogen $(\mathrm{T}-\mathrm{N})$, ortho phosphate-phosphorus $\left(\mathrm{PO}_{4}-\mathrm{P}\right)$, total-phosphorus (T-P), and electrical conductivity (EC), and the Irrigation for Plant Production Water Quality (IPP $\mathrm{NO}_{3}{ }^{-}-\mathrm{N}=10 \mathrm{mg} \cdot \mathrm{L}^{-1}$ is higher than the Y-axis range) and "Ecoregion IX Lake and Reservoir Ambient Water Quality" (E9LR) criteria; and of $(\mathbf{B})$ potassium $(\mathrm{K})$, calcium $(\mathrm{Ca})$, magnesium $(\mathrm{Mg})$, sulfur $(\mathrm{S}), \mathrm{pH}$, and total alkalinity (T-Alk) in a runoff containment basin in Maryland (MD21) in 2013.

well below IPP criteria during the entire sample period (Table 2). T-P levels $(0.234$ $\left.0.813 \mathrm{mg} \cdot \mathrm{L}^{-1}\right)$ greatly exceeded the E9LR 25 th percentile value for T-P, but were below IPP criteria during the entire sample period.

In MS11, the largest increase occurred with $\mathrm{NO}_{3}{ }^{-}-\mathrm{N}$ levels in August, which occurred synchronously with very small increases in $\mathrm{NH}_{4}{ }^{+}-\mathrm{N}, \mathrm{T}-\mathrm{P}, \mathrm{PO}_{4}-\mathrm{P}$, and $\mathrm{EC}$ levels (Fig. 3A; Table 3). Samples were taken later into the year from MS11 than the other RCBs. The $\approx \mathrm{T}-\mathrm{N}$ levels $(0.124-1.747$ $\mathrm{mg} \cdot \mathrm{L}^{-1}$ ) only exceeded the E9LR 25th percentile value for T-N levels in August and September and were well below IPP criteria (Table 2). T-P levels $\left(0.101-0.297 \mathrm{mg} \cdot \mathrm{L}^{-1}\right)$ were $\approx 3$ - to 10 -fold higher than the E9LR 25th percentile value for T-P, but were below IPP criteria during the entire sample period.

In VA10, no pronounced differences in $\mathrm{NO}_{3}{ }^{-} \mathrm{N}, \mathrm{NH}_{4}{ }^{+}-\mathrm{N}, \mathrm{T}-\mathrm{P}, \mathrm{PO}_{4}-\mathrm{P}$, and $\mathrm{EC}$ levels occurred through the sample period, except for a small decrease in $\mathrm{NO}_{3}{ }^{-}-\mathrm{N}$ levels (Fig. 4A; Table 3). $\mathrm{NO}_{3}{ }^{-}-\mathrm{N}$ levels were higher than many other RCBs, noted by a higher left $\mathrm{Y}$-axis scale in Fig. 4A. Furthermore, the $\approx \mathrm{T}-\mathrm{N}$ levels $\left(5.423-8.327 \mathrm{mg} \cdot \mathrm{L}^{-1}\right)$ well exceeded the E14LR 25th percentile value for $\mathrm{T}-\mathrm{N}$ during the entire sample period, but were still slightly below IPP criteria (Table 2). In contrast, T-P levels $\left(0.008-0.052 \mathrm{mg} \cdot \mathrm{L}^{-1}\right)$ were just above the E14LR 25th percentile value for T-P most months and just below the criteria in June, 
MS11

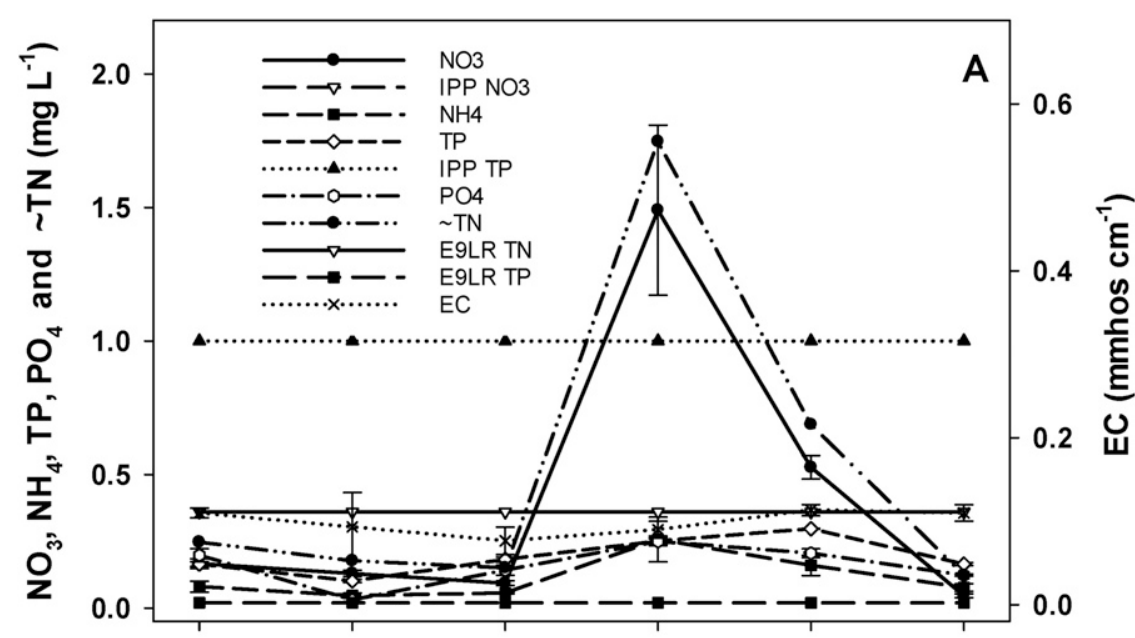

MS11

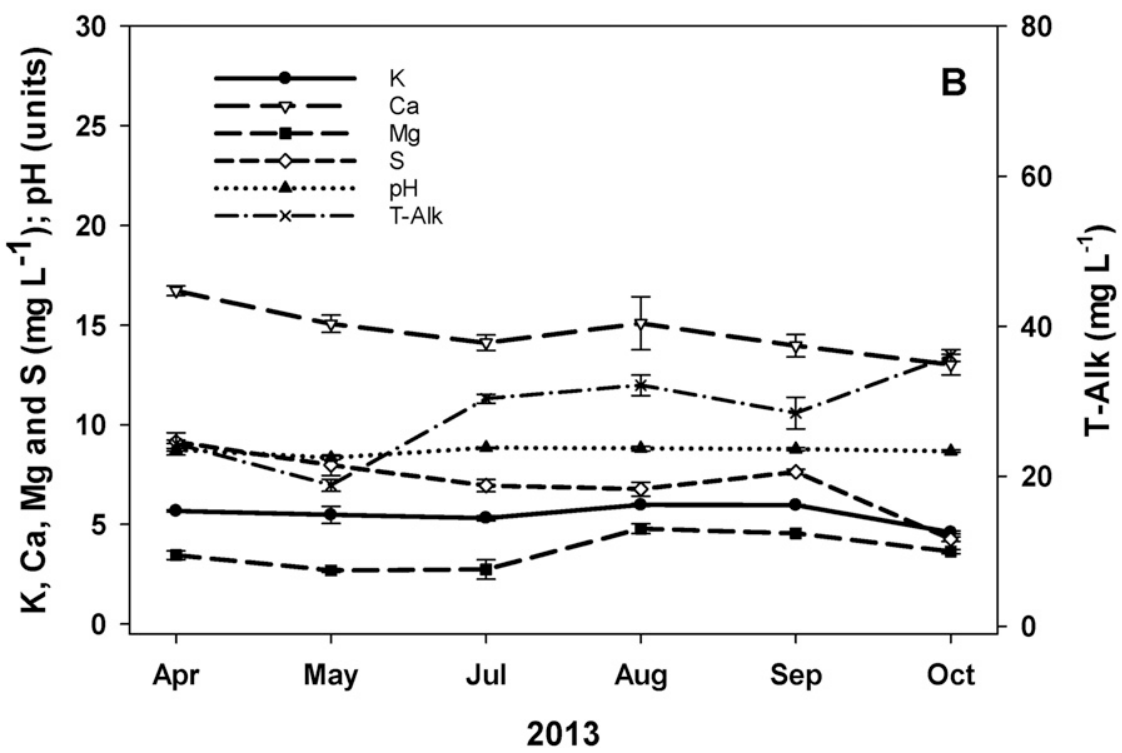

Fig. 3. Monthly mean levels $(n=6)$ of $(A)$ ammonium-nitrogen $\left(\mathrm{NH}_{4}{ }^{+}-\mathrm{N}\right)$, nitrate-nitrogen $\left(\mathrm{NO}_{3}{ }^{-}-\mathrm{N}\right)$, $\approx$ total-nitrogen $(\mathrm{T}-\mathrm{N})$, ortho phosphate-phosphorus $\left(\mathrm{PO}_{4}-\mathrm{P}\right)$, total-phosphorus $(\mathrm{T}-\mathrm{P})$, and electrical conductivity (EC), and the Irrigation for Plant Production Water Quality (IPP $\mathrm{NO}_{3}{ }^{-}-\mathrm{N}=10 \mathrm{mg} \cdot \mathrm{L}^{-1}$ is higher than the Y-axis range) and Ecoregion IX Lake and Reservoir Ambient Water Quality (E9LR) criteria; and of (B) potassium (K), calcium (Ca), magnesium $(\mathrm{Mg})$, sulfur $(\mathrm{S}), \mathrm{pH}$, and total alkalinity (T-Alk) in a runoff containment basin in Mississippi (MS11) in 2013.

and well below IPP criteria over the entire sample period.

In VA11, moderate to low synchronous increases occurred with $\mathrm{NO}_{3}^{-}-\mathrm{N}, \mathrm{NH}_{4}^{+}-\mathrm{N}$, $\mathrm{T}-\mathrm{P}, \mathrm{PO}_{4}-\mathrm{P}$, and $\mathrm{EC}$ in April and either remained elevated, decreased, or fluctuated in May and June (Fig. 5A; Table 3). $\mathrm{NO}_{3}{ }^{-}-\mathrm{N}$ levels were considerably higher than many other RCBs, noted by a higher left Y-axis scale in Fig. 5A. No water samples were collected in July. The $\approx \mathrm{T}-\mathrm{N}$ levels $(1.680$ $31.117 \mathrm{mg} \cdot \mathrm{L}^{-1}$ ) exceeded the E14LR 25th percentile value for $\mathrm{T}-\mathrm{N}$ during the entire sample period and also exceeded IPP criteria by 2 - to 3-fold in April, May, and June (Table 2). T-P levels $\left(0.469-3.785 \mathrm{mg} \cdot \mathrm{L}^{-1}\right)$ exceeded the E14LR 25th percentile value for T-P during the entire sample period and also exceeded IPP criteria by 2 - to 3 -fold in June and July.

In VA13, $\mathrm{NO}_{3}{ }^{-}-\mathrm{N}$ decreased over the sample period, whereas small synchronous increases in $\mathrm{PO}_{4}-\mathrm{P}$ and T-P occurred in June and July (Fig. 7A; Table 3). No water samples were collected in March. The $\approx \mathrm{T}-\mathrm{N}$ levels (0.040-1.123 $\mathrm{mg} \cdot \mathrm{L}^{-1}$ ) exceeded the E14LR 25 th percentile value for $\mathrm{T}-\mathrm{N}$ for February and April and were below the value from May to July, thus were well below IPP criteria during the entire sample period. T-P levels $\left(0.033-0.134 \mathrm{mg} \cdot \mathrm{L}^{-1}\right)$ exceeded the E9LR 25th percentile value for T-P during the entire sample period, but were below IPP criteria (Table 2).

In VA21, small asynchronous monthly changes occurred in water quality variables (Fig. 8A; Table 3). $\mathrm{NO}_{3}{ }^{-}-\mathrm{N}$ levels were low in March, decreased further in April and May, and then stayed very low through July, whereas $\mathrm{NH}_{4}{ }^{+}-\mathrm{N}$ levels increased in May and June. EC remained relatively constant over the sample period. No water samples were collected in February. The $\approx \mathrm{T}-\mathrm{N}$ levels (0.193-0.383 $\left.\mathrm{mg} \cdot \mathrm{L}^{-1}\right)$ initially were just above the E9LR 25th percentile value for $\mathrm{T}-\mathrm{N}$ in March and then decreased to below the criteria for the remainder of the sample period, thus were well below IPP criteria (Table 2). T-P levels $\left(0.065-0.157 \mathrm{mg} \cdot \mathrm{L}^{-1}\right)$ ranged from barely above the E9LR 25th percentile value for T-P to 2-fold levels higher, but were well below IPP criteria.

In VA22, small asynchronous monthly changes occurred in water quality variables (Fig. 9A; Table 3). $\mathrm{NO}_{3}{ }^{-}-\mathrm{N}$ and EC levels decreased from March through June. $\mathrm{NH}_{4}{ }^{+}-\mathrm{N}$ and $\approx \mathrm{T}-\mathrm{N}$ levels were very low, increased in May, and then decreased again in June. No water samples were collected in February. The $\approx \mathrm{T}-\mathrm{N}$ levels $\left(0.157-0.817 \mathrm{mg} \cdot \mathrm{L}^{-1}\right)$ were above the E9LR 25th percentile value for T-N in March through May and then declined below the value in June and July, but were well below IPP criteria (Table 2). T-P levels (0.021-0.100 $\mathrm{mg} \cdot \mathrm{L}^{-1}$ ) were above the E9LR 25th percentile value for T-P in April through July, but well below IPP criteria during the entire sample period.

In VA23, small asynchronous monthly changes occurred in water quality variables (Fig. 10A; Table 3). $\mathrm{NO}_{3}-\mathrm{N}$ and EC levels decreased from March through June. $\mathrm{NH}_{4}{ }^{+}-\mathrm{N}$ levels were very low in March and then increased through the sample period. The $\approx \mathrm{T}-\mathrm{N}$ decreased slightly in May and increased slightly in July. No water samples were collected in February. The $\approx \mathrm{T}-\mathrm{N}$ levels $\left(0.330-0.517 \mathrm{mg} \cdot \mathrm{L}^{-1}\right)$ were below the E9LR 25 th percentile value for $\mathrm{T}-\mathrm{N}$ in May and June and higher in all other months, but well below IPP criteria in the entire sample period (Table 2). T-P levels $(0.020-0.116$ $\mathrm{mg} \cdot \mathrm{L}^{-1}$ ) were above the E9LR 25 th percentile value for T-P for all months except March, but well below IPP criteria during the entire sample period.

For the other macronutrients $(\mathrm{K}, \mathrm{Ca}, \mathrm{Mg}$, and $\mathrm{S}$ ), the levels were relatively consistent through the sampling period in all RCBs 
VA10

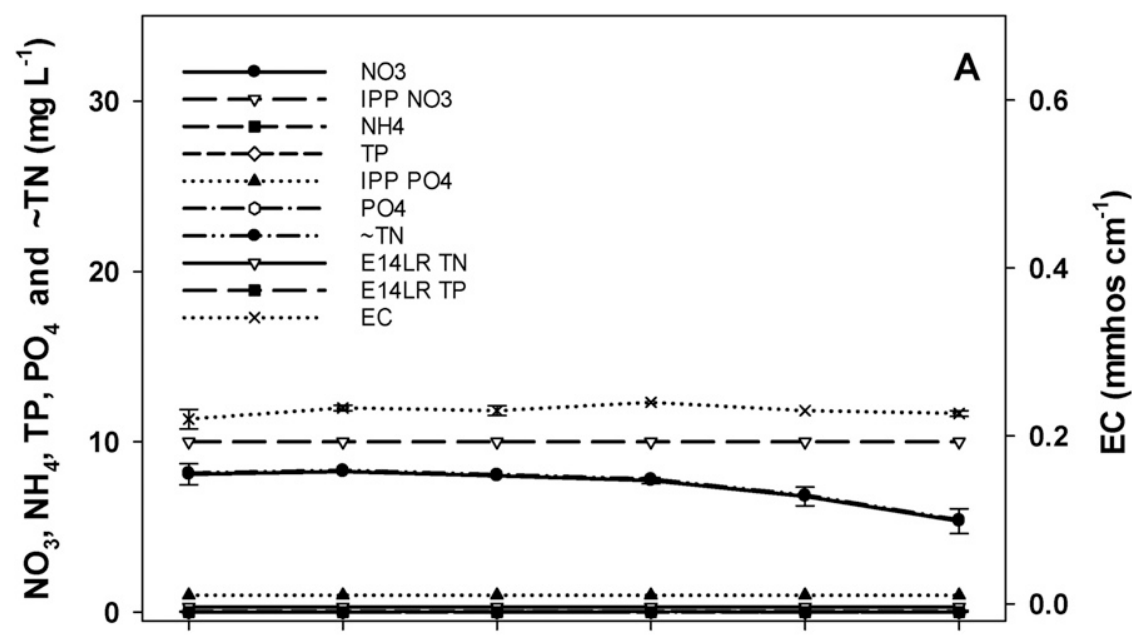

VA10

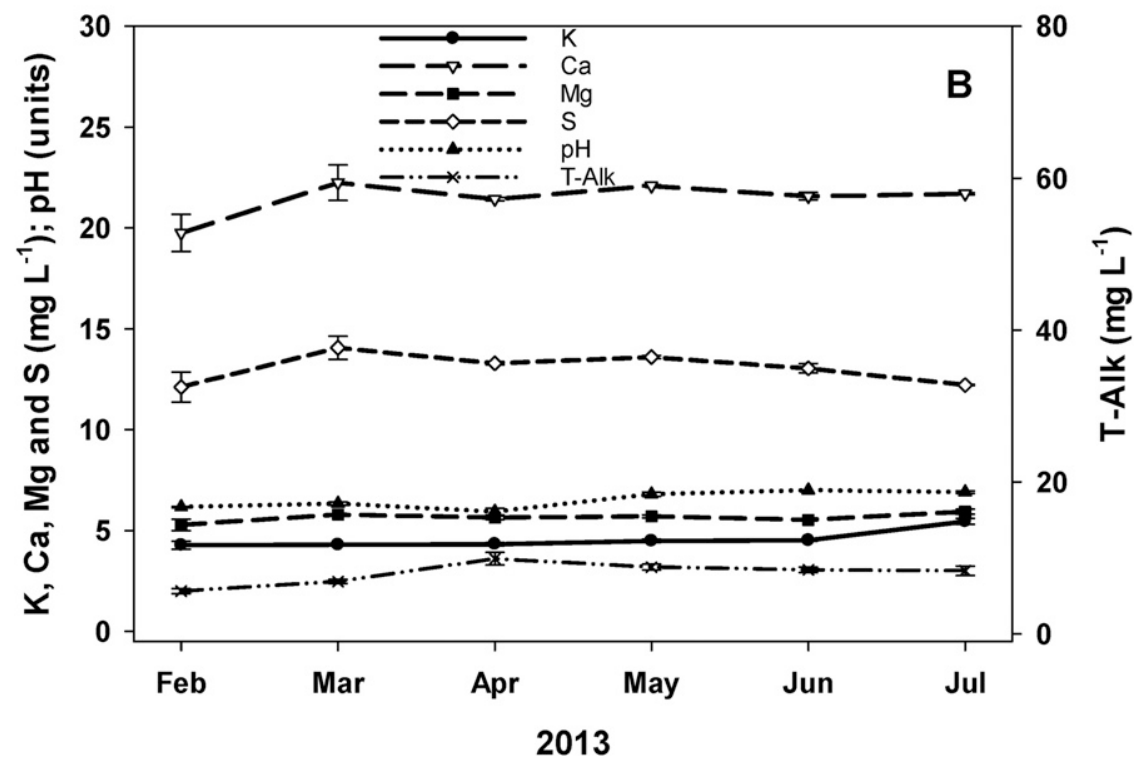

Fig. 4. Monthly mean levels $(n=6)$ of $(\mathbf{A})$ ammonium-nitrogen $\left(\mathrm{NH}_{4}{ }^{-}-\mathrm{N}\right)$, nitrate-nitrogen $\left(\mathrm{NO}_{3}{ }^{-}-\mathrm{N}\right)$,

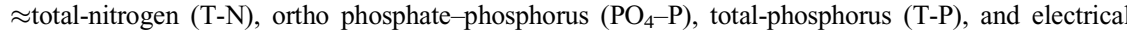
conductivity (EC), and the Irrigation for Plant Production Water Quality (IPP) and Ecoregion XIV Lake and Reservoir Ambient Water Quality (E14LR) criteria; and of (B) potassium (K), calcium (Ca), magnesium (Mg), sulfur (S), pH, and total alkalinity (T-Alk) in a stream in Virginia (VA10) in 2013.

(Figs. 1B-10B), although some significant differences occurred (Table 3). In MD11, Ca, $\mathrm{K}$, and $\mathrm{S}$ increased and decreased asynchronously with $\mathrm{N}$ and $\mathrm{P}$ variables (Fig. 1). In MD21, VA11, and VA12 RCBs, Ca, K, Mg, and $\mathrm{S}$ increased and decreased synchronously with $\mathrm{N}$ and $\mathrm{P}$ variables but to different degrees (Figs. 2, 5, and 6). Monthly changes in $\mathrm{Ca}, \mathrm{K}, \mathrm{Mg}$, and $\mathrm{S}$ levels were small in MS11, VA10, VA13, VA21, VA22, and VA23 (Figs. 3B, 4B, and 7B-10B).

$\mathrm{T}$-Alk and $\mathrm{pH}$ remained relatively consistent over the sampling period in all RCBs, although differences did occur between RCBs (Table 3). T-Alk fluctuated the greatest in MD11 and MD21 where the levels were moderate (Figs. 1B and 2B). T-Alk fluctuated less in the MS11, VA10, VA11, VA12, VA13, VA21, VA22, and VA23 RCBs where the levels were low $(<40)$ (Figs. 3B-10B). The $\mathrm{pH}$ units were $>7.5$ in most sampling months in MD11, MD21, and MS11 (Figs. 1B-3B); were $\leq 7.0$ in all sampling months in VA10, VA11, and VA12 (Figs. 4B-6B); and fluctuated above and below 7.5 , being $<7.5$ in most sampling months in VA13, VA21, VA22, and VA23 (Figs. 7B-10B)

Micronutrients $(\mathrm{Al}, \mathrm{B}, \mathrm{Cu}, \mathrm{Fe}, \mathrm{Mn}$, and $\mathrm{Zn)}$ were relatively constant over the sampling period in all RCBs, with some notable differences between RCBs (Table 3). Statistical differences did occur between months for some micronutrients in each RCB (Table 3), even though numerical ranges were small (data not shown). The largest ranges over the sampling period occurred with an increase in Al in June and July in
MD11 (minimum and maximum values, $0.083-0.180 \mathrm{mg} \cdot \mathrm{L}^{-1}$ ), an increase in $\mathrm{Al}$ in May and a decrease in June in VA13 (0.017$\left.0.071 \mathrm{mg} \cdot \mathrm{L}^{-1}\right)$, and an increase in $\mathrm{Fe}$ in June and July in VA22 $\left(0.098-0.502 \mathrm{mg} \cdot \mathrm{L}^{-1}\right)$ and VA23 $\left(0.097-0.775 \mathrm{mg} \cdot \mathrm{L}^{-1}\right)$.

\section{Discussion}

The pattern and degree of monthly changes in surface water nutrient, $\mathrm{pH}$, and ionic variables differed between RCBs, with no distinct pattern of monthly change being evident. Despite no distinct pattern of monthly change being representative of RCBs, synchronous changes occurred within several RCBs and some general patterns do exist. The most common patterns were either synchronized increases primarily between macronutrients from late spring into summer or month-to-month fluctuating increases and decreases. The most obvious explanation of increases and decreases, respectively, would result from nutrient releases from CRFs and water-soluble fertilizers in leachate runoff, and dilution from large rainfall volumes. The dynamic nature of water quality variables undoubtedly add to some of the seemingly erratic monthly changes that occurred, being influenced by hydrological (stratification, stoichiometry of nutrients, and light transmittance), geological (geological character of bottom sediment and saturation of nutrients in sediment), biological (rates of phytoplankton growth and structure of phytoplankton communities), and meteorological (temperature, rainfall, wind, and seasonal fluctuations) conditions, thus making any simple deductive explanations inappropriate without more extensive sampling (Boström et al., 1988; Burgin and Hamilton, 2007; Dodds, 1993; Hong et al., 2009; McCarthy et al., 2007; McEnroe et al., 2013; Scheffer and van Nes, 2007; Steegen et al., 2001; Steele et al., 2010; Yang et al., 2008, 2016; Zhu et al., 2007, 2010).

Interesting patterns emerged when considering $\mathrm{N}$ and $\mathrm{P}$ levels relative to plant production and ecological criteria, such as whether $\approx \mathrm{T}-\mathrm{N}$ and T-P levels fell below or above the E9LR, E14LR, or IPP criteria (Robbins, 2010; USEPA, 2000, 2001). Differences between the E9LR, E14LR, and other ecoregions will not be discussed here and will be treated as if they are equal based on water conditions being equally representative of respective ecoregions. The $\approx \mathrm{T}-\mathrm{N}$ and T-P levels were lowest in VA22 and $\mathrm{VA23}$, whereby $\approx \mathrm{T}-\mathrm{N}$ was within the E9LR 25 th percentile value throughout the sample period and T-P was within the E9LR range during March, April, and May and then rose above it in June and July. Neither of these RCBs receives runoff directly. Algae was more a problem late in the summer in these RCBs, which would be expected based on E9LR criteria for T-P. T-P is considered a limiting nutrient for promoting algal bloom occurrence (Kim et al., 2007; Yang et al., 2008). VA21 had a similar pattern to VA22 and VA23, with the main difference being 
VA11

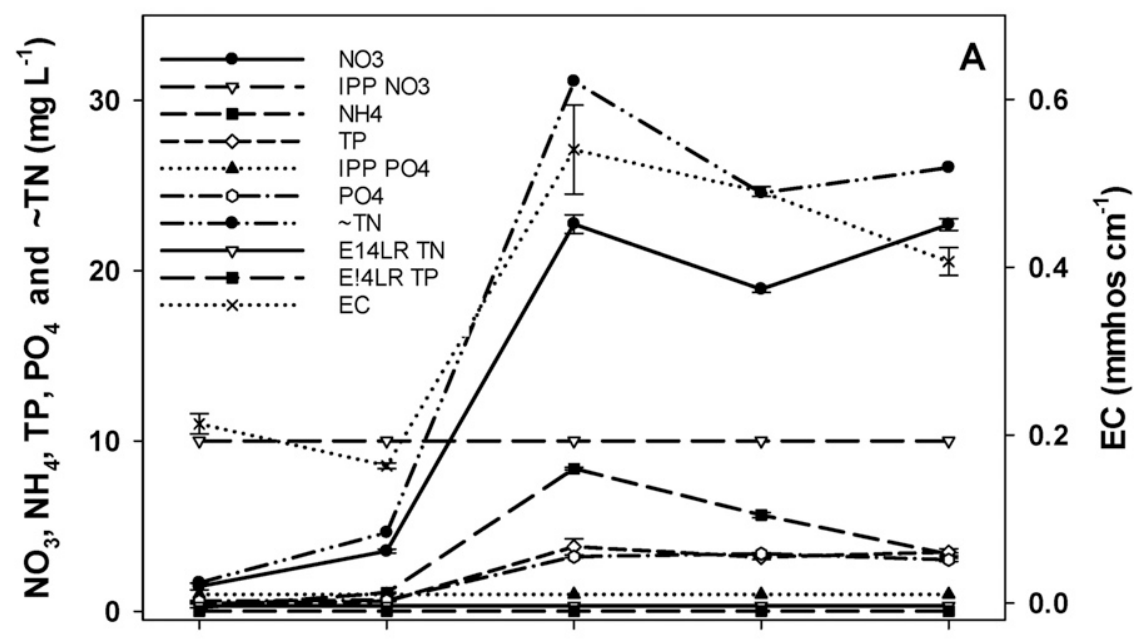

VA11

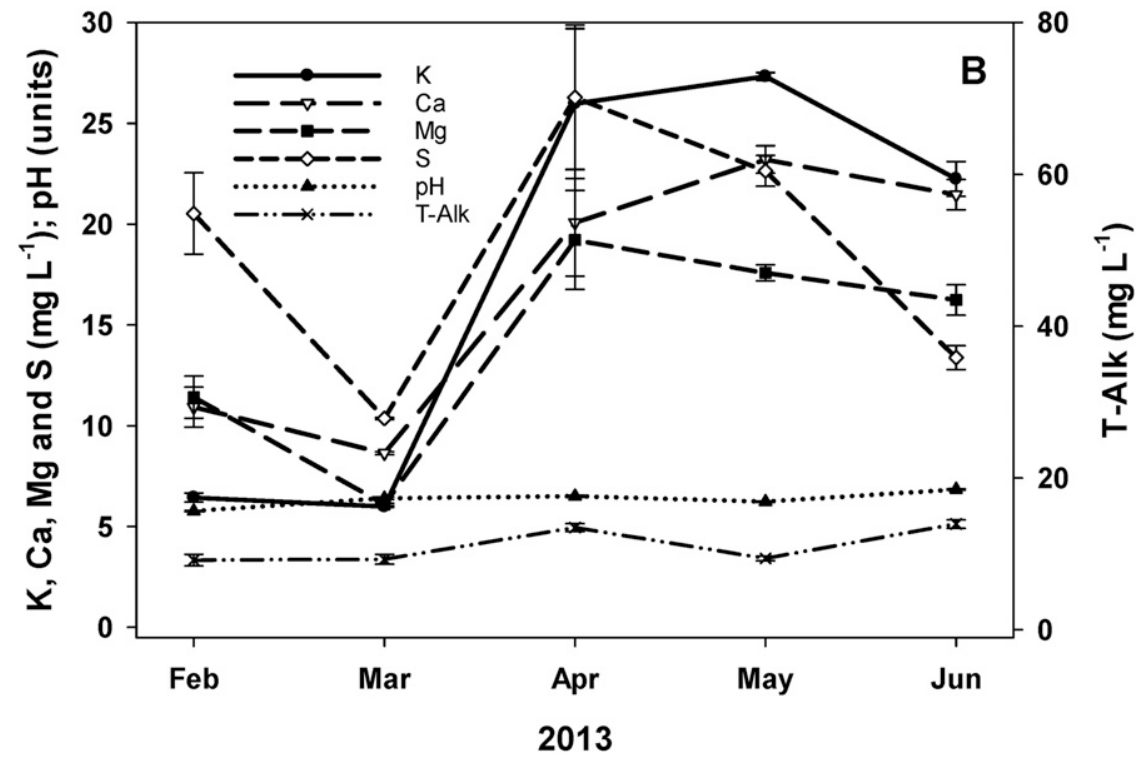

Fig. 5. Monthly mean levels $(n=5)$ of $(\mathbf{A})$ ammonium-nitrogen $\left(\mathrm{NH}_{4}{ }^{+}-\mathrm{N}\right)$, nitrate-nitrogen $\left(\mathrm{NO}_{3}{ }^{-} \mathrm{N}\right)$, $\approx$ total-nitrogen $(\mathrm{T}-\mathrm{N})$, ortho phosphate-phosphorus $\left(\mathrm{PO}_{4}-\mathrm{P}\right)$, total-phosphorus (T-P), and electrical conductivity (EC), and the Irrigation for Plant Production Water Quality (IPP) and Ecoregion XIV Lake and Reservoir Ambient Water Quality (E14LR) criteria; and of (B) potassium (K), calcium (Ca), magnesium (Mg), sulfur (S), $\mathrm{pH}$, and total alkalinity (T-Alk) in a runoff containment basin in Virginia (VA11) in 2013

T-P exceeded the E9LR 25th percentile value during the entire sample period. VA21 does receive runoff directly from the nursery. VA2 had the smallest production area of nurseries included in the study, plus it had a three pond system; thus, the capacity of the pond system could partly explain why it had the fewest water quality levels that exceeded IPP criteria.

The more common pattern was that both $\approx \mathrm{T}-\mathrm{N}$ and T-P levels exceeded the Ecoregion 25 th percentile values for some months but remained below IPP criteria. Of these, MD21 and MS11 had $\approx \mathrm{T}-\mathrm{N}$ levels below the E9LR 25 th percentile value for most months, but exceeded the range for 1 or 2 months, whereas T-P levels exceeded the E9LR 25th percentile value during the entire sample period. MD11, VA10, and VA13 had both $\approx \mathrm{T}-\mathrm{N}$ and $\mathrm{T}-\mathrm{P}$ levels exceeding E14LR criteria most or all months during the sample period. In these cases, both $\mathrm{N}$ and $\mathrm{P}$ are available for contributing to growth of phytoplankton populations (McCarthy et al., 2007; Yang et al., 2008). Algal blooms can be dense in these RCBs, which is common, even though water quality from these RCBs was classified as acceptable for plant production.

In the more severe cases, $\approx \mathrm{T}-\mathrm{N}$ and $\mathrm{T}-\mathrm{P}$ levels exceeded IPP criteria in VA11 and VA12 during June and July, and well exceeded E14LR criteria during the entire sample period. VA11 is a small shallow sedimentation RCB (1012 $\mathrm{m}^{2}$ surface area) that receives runoff directly from the nursery (Zhang et al., 2016). Because of its small size, VA11 overflows regularly into VA12, which serves as a larger retention pond of $8064 \mathrm{~m}^{2}$ surface area. The vast majority of water variables in VA11, such as macronutrients, peaked in April, whereas other water variables peaked in May, particularly some of the micronutrients. Levels in VA12 typically lagged VA11 by 1 month, which was the smallest temporal sampling unit increment. VA12 is used as a water source for irrigating plants; therefore, high $\approx \mathrm{T}-\mathrm{N}$ and T-P levels invoke concern about plant health. However, during this period, no plant quality concerns were observed by nursery production managers. Many nutrients remained relatively elevated over the sample period probably because of regular release of CRFs. The similarity of the pattern between VA11 and VA12 indicate a conserved persistence of elements, even if elemental form might have changed. This is an example where reducing the daily water applied through irrigation might achieve reductions in runoff, thus in $\mathrm{NO}_{3}{ }^{-}-\mathrm{N}$ and $\mathrm{PO}_{4}-\mathrm{P}$ leachates (Pershey et al., 2015). An interesting fact was that $\mathrm{pH}$ levels were more suitable in these RCBs than any of the other RCBs. A direct relationship between nutrient levels was not apparent between VA12 and VA13. This is understandable because overflow from VA12 to VA13 is manually regulated by the grower, so occurs less frequently than between VA11 and VA12, plus VA13 is considerably larger, having $60,703 \mathrm{~m}^{2}$ surface area.

One purpose of RCBs is to capture and contain leachates on the property so they do not add nonpoint pollution to downstream waterways. RCBs provide a contribution and investment to the surrounding ecology and local community. In the process, eutrophication becomes a problem in the RCBs vs contributing to it downstream. Algal blooms are common in RCBs and are part of the concern about RCB water quality. Algal blooms occur annually in all nine of the RCBs. Zhang et al. (2016) found algal blooms mostly concentrated in the thermocline layer during stratification of RCBs on VA1 and VA2. Kong et al. (2017) found different population structures of cyanobacteria, eukaryotic phytoplankton, and other bacteria in each of the RCBs on VA1 and VA2. Eutrophication is a major concern of USEPA criteria and is influenced by several water quality factors, including nutrient enrichment, biodiversity, lake morphology and hydrology, groundwater hydrology, and water conditions such as temperature (NaselliFlores and Barone, 2000; Scheffer and van Nes, 2007; Yang et al., 2008). Several management options could help minimize eutrophication in RCBs. Limiting runoff can help achieve lower nutrient transfer to the RCB (Bilderback, 2002; Yeager and Cashion, 1993). Fertilizer rates are not standardized and vary from amounts greater than plant needs to plant species-specific needs (Yeager and Cashion, 1993). Wilson et al. (2010) measured low to high levels of $\mathrm{NO}_{3}-\mathrm{N}$ concentrations, from 0.7 to $386.4 \mathrm{mg} \cdot \mathrm{L}^{-1}$, in runoff on nurseries. Nutrient levels in runoff would be diluted on flowing into an RCB. 
VA12

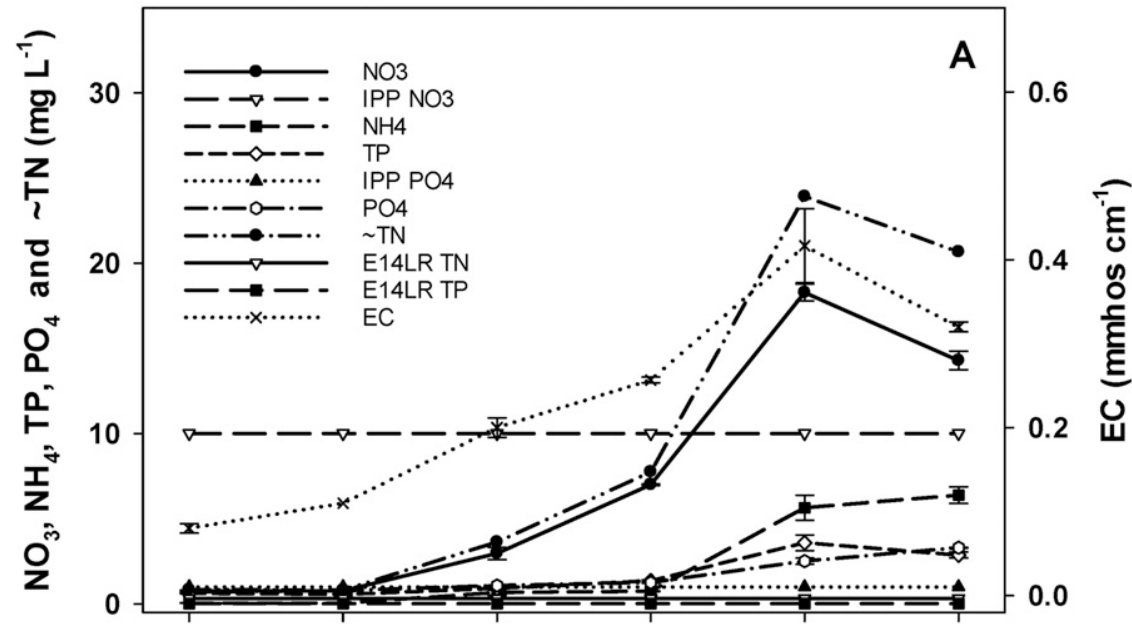

VA12

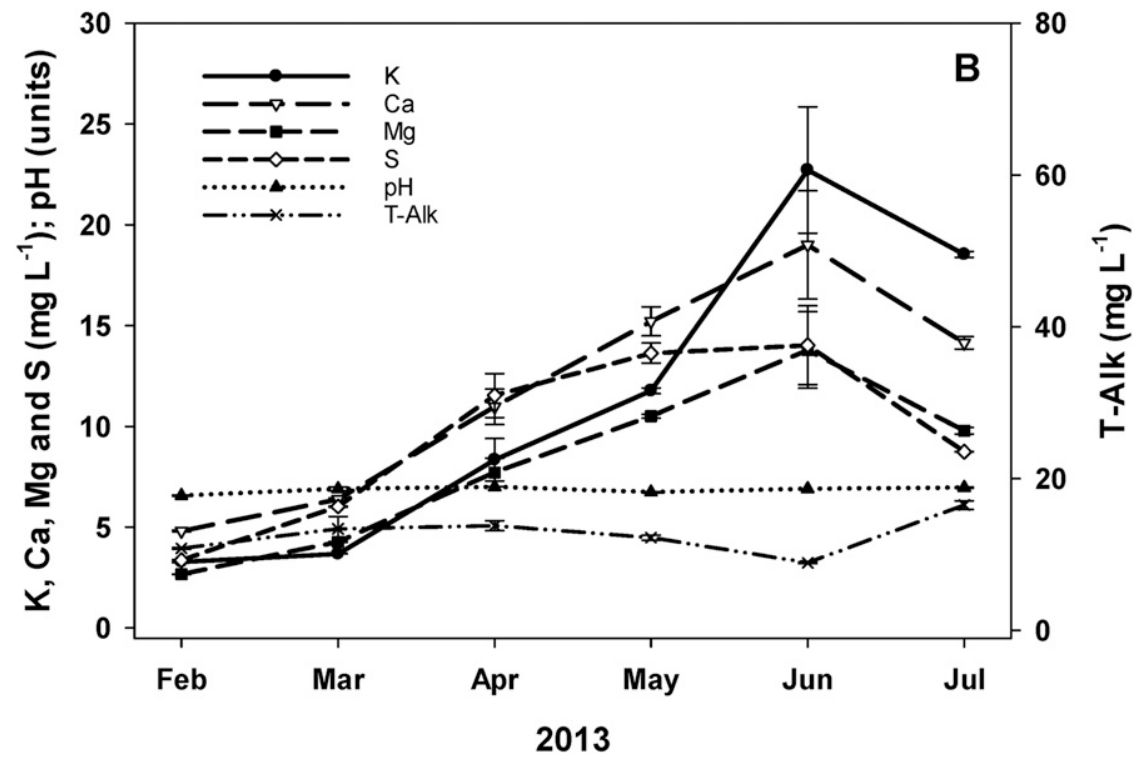

Fig. 6. Monthly mean levels $(n=6)$ of $(\mathbf{A})$ ammonium-nitrogen $\left(\mathrm{NH}_{4}{ }^{+}-\mathrm{N}\right)$, nitrate-nitrogen $\left(\mathrm{NO}_{3}{ }^{-}-\mathrm{N}\right)$, $\approx$ total-nitrogen $(\mathrm{T}-\mathrm{N})$, ortho phosphate-phosphorus $\left(\mathrm{PO}_{4}-\mathrm{P}\right)$, total-phosphorus $(\mathrm{T}-\mathrm{P})$, and electrical conductivity (EC), and the Irrigation for Plant Production Water Quality (IPP) and Ecoregion XIV Lake and Reservoir Ambient Water Quality (E14LR) criteria; and of (B) potassium (K), calcium (Ca), magnesium $(\mathrm{Mg})$, sulfur $(\mathrm{S}), \mathrm{pH}$, and total alkalinity (T-Alk) in a runoff containment basin in Virginia (VA12) in 2013

Storm flow could further dilute water variables in RCBs (Myers, 2015). Irrigation volumes and frequencies can effect runoff volumes and $\mathrm{NO}_{3}-\mathrm{N}$ and $\mathrm{PO}_{4}-\mathrm{P}$ leachate rates (Birrenkott et al., 2005; Pershey et al., 2015; Warsaw et al., 2009a). The present study shows that water quality levels in RCBs can be negatively and positively affected. Leachate runoff and storm flow were not monitored in the present study; thus, contribution to management techniques were not evaluated.

Another observation was the irregular proportional balance between water quality variables within RCBs. Unique differences were found in several RCBs, examples included higher $\mathrm{NO}_{3}-\mathrm{N}$ levels relative to $\mathrm{NH}_{4}{ }^{+}-\mathrm{N}$ levels in MD21, MS11, and VA10; high $\mathrm{Ca}$ levels in MD21; fluctuating Al levels a relatively sharp increase in $\mathrm{K}, \mathrm{Ca}, \mathrm{B}, \mathrm{Cu}$, $\mathrm{Zn}$, and EC levels were measured in May; $\mathrm{Al}$ in June; and gradual increases over the season in $\mathrm{PO}_{4}-\mathrm{P}, \mathrm{T}-\mathrm{P}$, and $\mathrm{Mg}$ levels. Pulling a water sample could alert growers to fertilizer practices having unintended consequences.

The one stream (VA10) that was sampled for comparison with VA11, VA12, and VA13 showed a different pattern than any of the RCBs. Monthly values from the stream were not significantly different for 15 of 18 water quality variables and only small differences were measured for the other three variables $\left(\mathrm{NO}_{3}{ }^{-}-\mathrm{N}\right.$, $\mathrm{pH}$, and $\left.\mathrm{Zn}\right)$. Thus, overall water quality in the stream was considerably more consistent between February and July than any of the RCBs. The monthly stream profile indicates that a large nutrient source, such as large agricultural acreage, may not contribute prominently to VA10 above this point (Chambers et al., 2012). Unlike RCBs that are constructed as a catchment for a defined production area, streams are part of a watershed for a larger land mass. Seasonal variation in water quality of streams will be dependent on many hydrochemical processes, rainfall, solute runoff from land, vegetation coverage, physical catchment characteristics, groundwater chemistry, etc. (Chambers et al., 2012; Piñol et al., 1992; Steegen et al., 2001).

Seasonal variations in water quality add a temporal dimension to assessing water quality. Zhang et al. (2015b, 2016) showed annual seasonal vertical variations in water quality of some of these same RCBs, stratification being the most prominent event. However, the importance of which variable contributes to water quality variation differs per season and per waterway (Ouyang et al., 2006; Piñol et al., 1992; Zhang et al., 2015b, 2016). In addition, seasonal differences between spring and summer would be confounded by fertilizer practices (fertilizer type, time of application, and rate) and the effect of temperature and rainfall on release rates of CRFs.

Research also shows that plant pathogen dispersal and survival in RCBs is influenced by water quality (Kong and Hong, 2014; Kong and Lea-Cox, 2014; Kong et al., 2012a, 2012b). Low EC levels, typical of the RCBs studied, is unfavorable for several plant pathogenic Phytophthora spp. Water $\mathrm{pH}$ varied considerably between RCBs. Because Phytophthora spp. vary in their preference to $\mathrm{pH}$, the potential for which Phytophthora spp. survives could vary for each RCB (Kong et al., 2009). Although this area of information has limited development at this time, it is a potentially important consideration relative to water quality.

Systematic evaluations are needed to better understand what detrimentally influences water quality from a plant production consideration, which potentially could include excessive nutrient levels and pesticide residuals (Mangiafico et al., 2009). Several studies indicate nutrient, $\mathrm{pH}$, alkalinity, and ionic properties of water quality of many operations are not hurting plant growth (Chen 
VA13

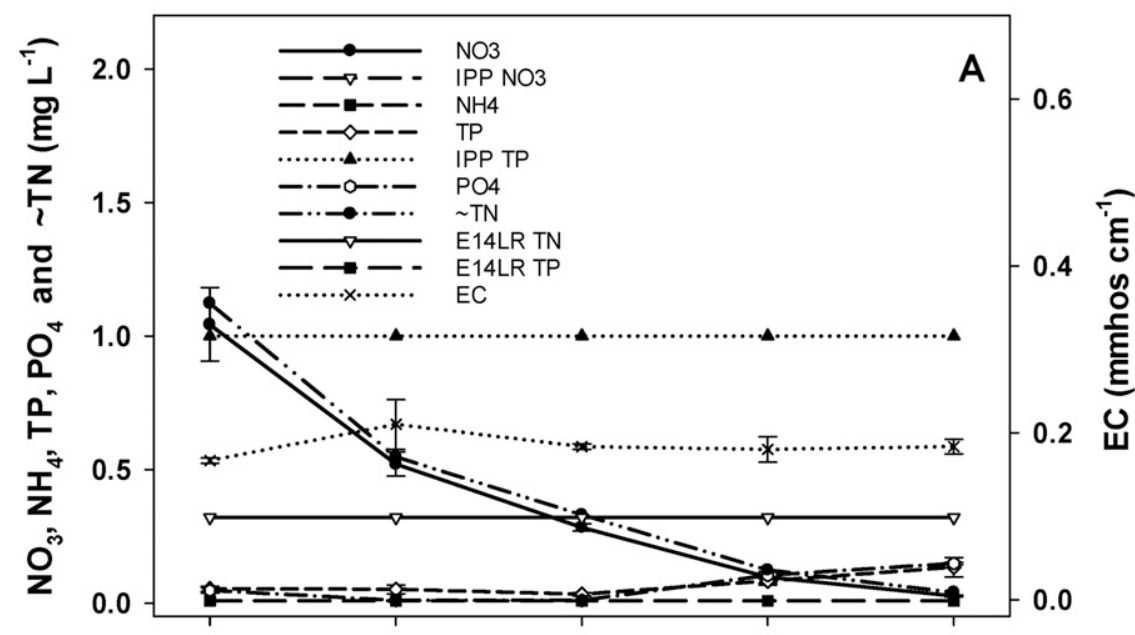

VA13

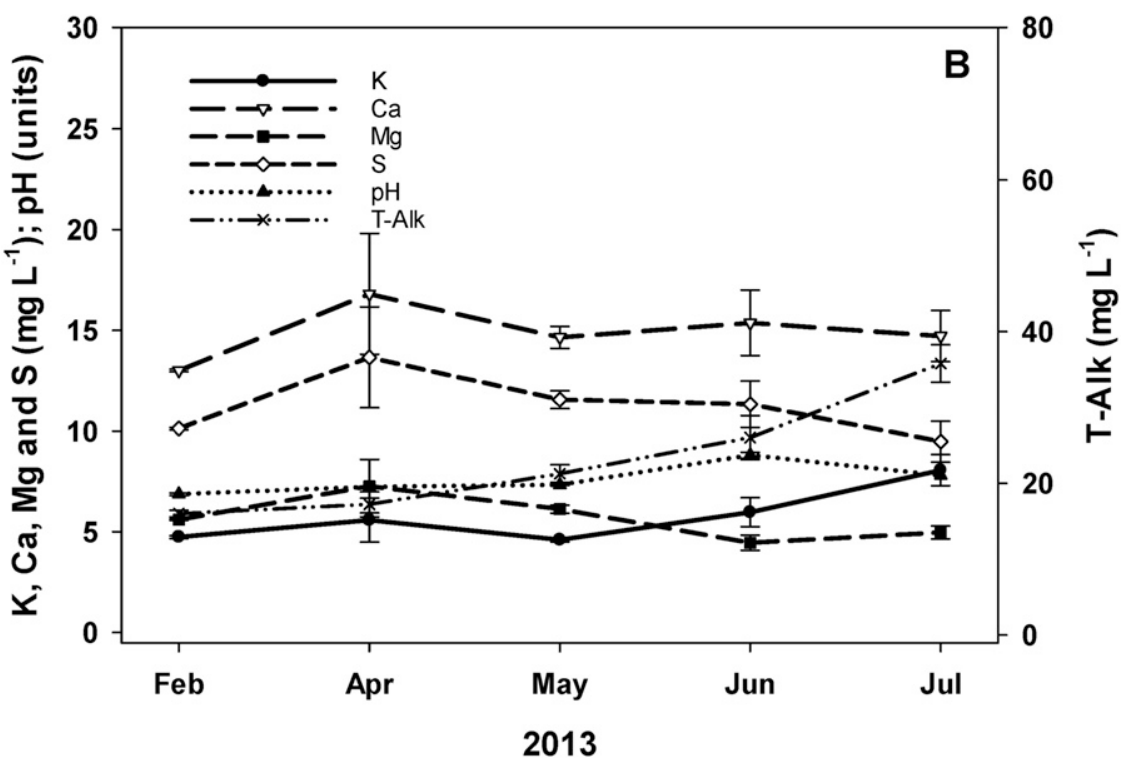

Fig. 7. Monthly mean levels $(n=5)$ of $(\mathbf{A})$ ammonium-nitrogen $\left(\mathrm{NH}_{4}{ }^{-}-\mathrm{N}\right)$, nitrate-nitrogen $\left(\mathrm{NO}_{3}{ }^{-}-\mathrm{N}\right)$, $\approx$ total-nitrogen $(\mathrm{T}-\mathrm{N})$, ortho phosphate-phosphorus $\left(\mathrm{PO}_{4}-\mathrm{P}\right)$, total-phosphorus (T-P), and electrical conductivity (EC), and the Irrigation for Plant Production Water Quality (IPP $\mathrm{NO}_{3}{ }^{-}-\mathrm{N}=10 \mathrm{mg} \cdot \mathrm{L}^{-1}$ is higher than the Y-axis range) and Ecoregion XIV Lake and Reservoir Ambient Water Quality (E14LR) criteria; and of $(\mathbf{B})$ potassium $(\mathrm{K})$, calcium $(\mathrm{Ca})$, magnesium $(\mathrm{Mg})$, sulfur $(\mathrm{S}), \mathrm{pH}$, and total alkalinity (T-Alk) in a runoff containment basin in Virginia (VA13) in 2013.

and Beeson, 2004; Chen et al., 2003; Copes et al., 2017), whereas a few studies have shown water quality can hurt plant growth (Meador et al., 2012; Valdez-Aguilar et al., 2009). Salinity is one variable that has been shown to effect quality of ornamental plants (Devitt et al., 2005). Many informational and extension bulletins address the salinity issue for traditional agricultural and horticultural crops, but EC and salinity levels of the RCBs were considerably lower than levels where damage occurs. Because water nutrient, $\mathrm{pH}$, and ionic variables do not appear to be prominent factors associated in inhibiting plant growth, a compilation is needed of actual diagnoses of factors (nutrients, salinity, pesticide residues, phytoplankton populations, etc.) negatively impacting plant growth, so specific criteria can be developed for diagnosing recycling irrigation water quality for plant production. Factors affecting water flow through irrigation lines need to be part of these considerations.

\section{Conclusions}

Levels of $\mathrm{NO}_{3}{ }^{-}-\mathrm{N}, \mathrm{NH}_{4}{ }^{+}-\mathrm{N}, \mathrm{PO}_{4}-\mathrm{P}, \mathrm{T}-\mathrm{P}$, $\mathrm{K}, \mathrm{Ca}, \mathrm{Mg}, \mathrm{S}, \mathrm{Al}, \mathrm{B}, \mathrm{Cu}, \mathrm{Fe}, \mathrm{Mn}, \mathrm{Zn}, \mathrm{pH}$, T-Alk, EC, and Na were mostly below IPP criteria in the RCBs sampled, thus within or below preferred levels for irrigation of plants. Runoff from container-grown plants fertilized with CRFs did result in increases in nutrient levels in the $\mathrm{RCBs}$, mainly for macronutrients a month or two after CRFs were applied to container-grown plants. In only two RCBs at one nursery were levels higher than IPP criteria, and then $\mathrm{NO}_{3}{ }^{-}-\mathrm{N}$,
$\mathrm{NH}_{4}^{+}-\mathrm{N}, \mathrm{PO}_{4}-\mathrm{P}$, T-P levels exceed IPP criteria in June and July only. Regardless, no negative impact on plant growth or quality was observed by production managers at that nursery. Across all the nurseries, $\mathrm{pH}$ varied widely from mildly acidic to alkaline, but monthly changes in $\mathrm{pH}$ tended to be small within an RCB. In the RCBs which have $\mathrm{pH}$ levels greater than 7.5, water needs to be acidified before adding certain disinfectants, such as chlorine products (except chlorine dioxide), peroxygen compounds, and ozone. The uniqueness of each of the RCBs in the study highlights the fact that assumptions should not be made about water quality without testing water qualities. However, interpretive determination of how water quality influences plant health is still limited.

Despite water quality levels from these RCBs being favorable for irrigating plants, $\mathrm{T}$ $\mathrm{P}$ levels often and $\approx \mathrm{T}-\mathrm{N}$ levels occasionally were greater than USEPA criteria, therefore likely favorable for development of algal blooms. However, containment of fertilizer leachates is a positive attribute to the surrounding community, whereby nurseries do not contribute to off-site pollution of downstream waterways. Results show the possibility that many nurseries may be maintaining nutrient, $\mathrm{pH}$, alkalinity, and ionic variables favorable for plant production and even achieving T-N and T-P levels near USEPA standards, which is encouraging. Monitoring and implementation of known management strategies could minimize algal blooms and maintain an ecologically healthier water environment, whereas reducing fertilizer costs. Presently, more comprehensive criteria are needed to better define water quality criteria appropriate for commercial ornamental crop production in diverse geological, geographical, and climatic regions.

\section{Literature Cited}

Argo, W.R. and J.A. Biernbaum. 1996. The effect of lime, irrigation-water source, and watersoluble fertilizer on the $\mathrm{pH}$ and macronutrient management of container root media with impatiens. J. Amer. Soc. Hort. Sci. 121:442452.

Bilderback, T.E. 2002. Water management is key in reducing nutrient run-off from container nurseries. HortTechnology 12:541-544.

Bilderback, T.E., S.L. Warren, and J.H. Daniels. 1999. Managing irrigation by electrical conductivity. Acta Hort. 481:403-408.

Birrenkott, B.A., J.L. Craig, and G.R. McVey. 2005. A leach collection system to track the release of nitrogen from controlled-release fertilizers in container ornamentals. HortScience 40:1887-1891.

Boström, B., J.M. Andersen, S. Fleischer, and M. Jansson. 1988. Exchange of phosphorus across the sediment-water interface. Hydrobiologia 170:229-244.

Burgin, A.J. and S.K. Hamilton. 2007. Have we overemphasized the role of denitrification in aquatic ecosystems? A review of nitrate removal pathways. Front. Ecol. Environ. 5:8996.

Chambers, P.A., D.J. McGoldrick, R.B. Brua, C. Vis, J.M. Culp, and G.A. Benoy. 2012. 
VA21

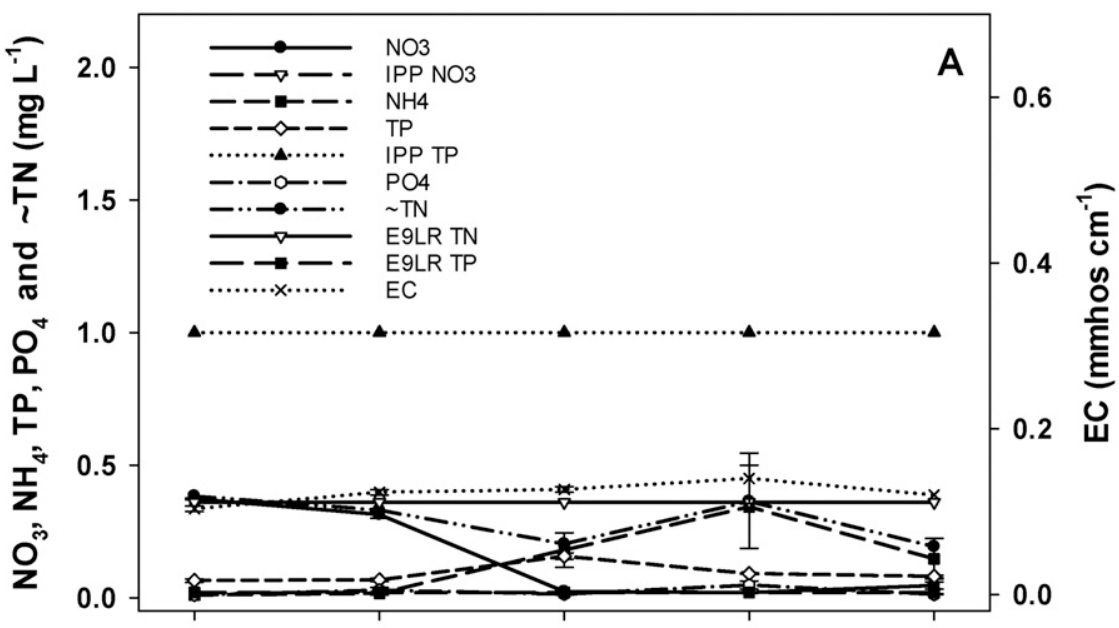

VA21

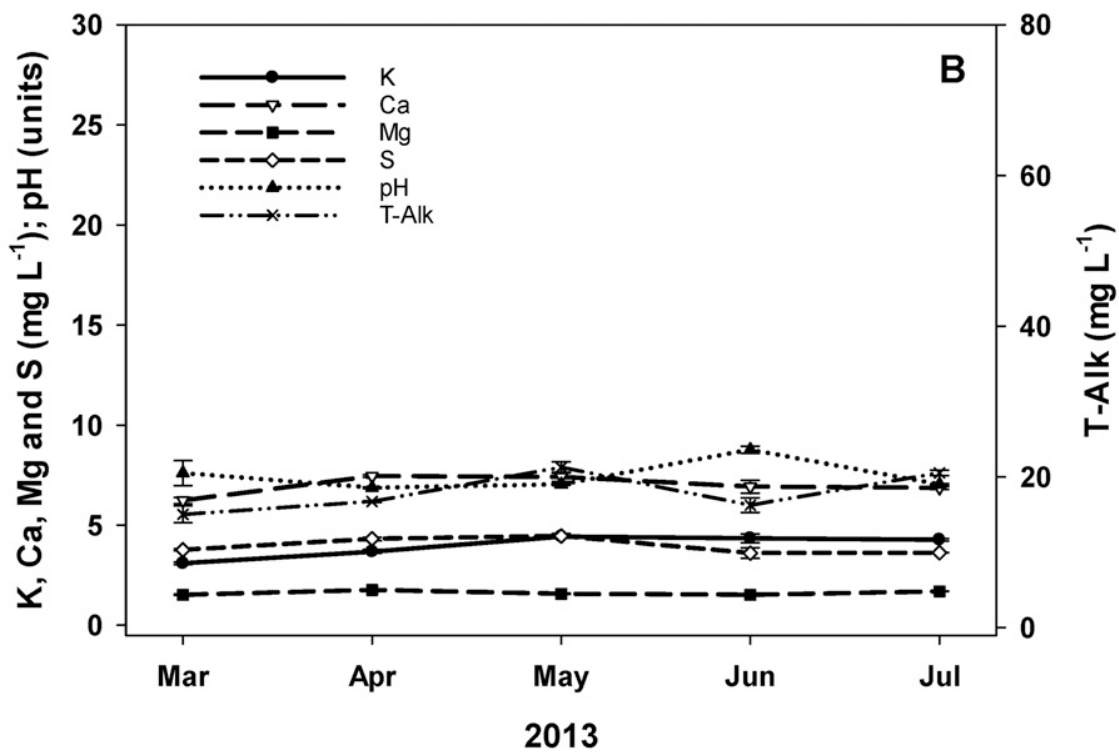

Fig. 8. Monthly mean levels $(n=5)$ of $(\mathbf{A})$ ammonium-nitrogen $\left(\mathrm{NH}_{4}{ }^{+}-\mathrm{N}\right)$, nitrate-nitrogen $\left(\mathrm{NO}_{3}{ }^{-}-\mathrm{N}\right)$, $\approx$ total-nitrogen $(\mathrm{T}-\mathrm{N})$, ortho phosphate-phosphorus $\left(\mathrm{PO}_{4}-\mathrm{P}\right)$, total-phosphorus (T-P), and electrical conductivity (EC), and the Irrigation for Plant Production Water Quality (IPP $\mathrm{NO}_{3}{ }^{-}-\mathrm{N}=10 \mathrm{mg} \cdot \mathrm{L}^{-1}$ is higher than the Y-axis range) and Ecoregion IX Lake and Reservoir Ambient Water Quality (E9LR) criteria; and of $(\mathbf{B})$ potassium $(\mathrm{K})$, calcium $(\mathrm{Ca})$, magnesium $(\mathrm{Mg})$, sulfur $(\mathrm{S}), \mathrm{pH}$, and total alkalinity (T-Alk) in a runoff containment basin in Virginia (VA21) in 2013.

Development of environmental thresholds for nitrogen and phosphorus in streams. J. Environ. Qual. 41:7-20.

Chen, J. and R.C. Beeson, Jr. 2004. Production of quality aroid foliage plants using captured rainwater and irrigation run-off as an irrigation source. Acta Hort. 664:139-145.

Chen, J., R.C. Beeson, T.H. Yeager, R.H. Stamps, and L.A. Felter. 2003. Evaluation of captured rainwater and irrigation run-off for greenhouse foliage and bedding plant production. HortScience 38:228-233.

Chiandet, A.S. and M. Xenopoulos. 2016. Landscape and morphometric controls on water quality in stormwater management ponds. Urban Ecosyst. 19:1645-1663.

Copes, W.E., X. Yang, and C.X. Hong. 2015. Phytophthora species recovered from irrigation reservoirs in Mississippi and Alabama nurseries and pathogenicity of three new species. Plant Dis. 99:1390-1395.
Copes, W.E., H. Zhang, P.A. Richardson, B.E. Belayneh, A. Ristvey, J. Lea-Cox, and C. Hong. 2017. Nutrient, pH, alkalinity, and ionic property levels in run-off containment basins in Alabama, Louisiana, Maryland, Mississippi and Virginia ornamental plant nurseries. HortScience 52:641-648

Devitt, D.A., R.L. Morris, L.K. Fenstermaker, M. Baghzouz, and D.S. Neuman. 2005. Foliar damage and flower production of landscape plants sprinkle irrigated with reuse water. HortScience 40:1871-1878.

Dodds, W.K. 1993. What controls levels of dissolved phosphate and ammonium in surface waters? Aquat. Sci. 55:132-142.

Dole, J.M., P. Fisher, and B.E. Whipker. 2011. Water quality, p. 9-20. In: J. Nau (ed.). Ball redbook: Crop production, Vol. 2. Ball Publishing, West Chicago, IL.

Evans-White, M.A., B.E. Haggard, and J.T. Scot. 2013. A review of stream nutrient criteria development in the United States. J. Environ. Qual. 42:1002-1014.

Havens, K.E., K.R. Jin, N. Iricanin, and R.T. James. 2007. Phosphorus dynamics at multiple time scales in the pelagic zone of a large shallow lake in Florida, USA. Hydrobiologia 581:25-42.

Hem, J.D. 1985. Study and the interpretation of chemical characteristics of natural water. U.S. Geolog. Surv., water supply paper 2254.

Hong, C., J.D. Lea-Cox, D.S. Ross, G.W. Moorman, P.A. Richardson, S.R. Ghimire, and P. Kong. 2009. Containment basin water quality fluctuation and implications for crop health management. Irr. Sci. 27:485-496.

Kim, H.S., S.J. Hwang, J.K. Shin, K.G. An, and C.G. Yoon. 2007. Effects of limiting nutrients and $\mathrm{N}: \mathrm{P}$ ratios on the phytoplankton growth in a shallow hypertrophic reservoir. Hydrobiologia 581:255-267.

Kong, P. and C. Hong. 2014. Oxygen stress reduces zoospore survival of Phytophthora species in a simulated aquatic system. BMC Microbiol. 14:124.

Kong, P. and J.D. Lea-Cox. 2014. Water quality dynamics and influences on pathogen mitigation in irrigation reservoirs, p. 333-346. In: C.X. Hong, G.W. Moorman, W. Wohanka, and C. Buettner (eds.). Biology, detection and management of plant pathology in irrigation water. APS Press, St Paul, MN

Kong, P., J.D. Lea-Cox, and C.X. Hong. 2012a Effect of electrical conductivity on survival of Phytophthora alni, P. kernoviae and P. ramorum in a simulated aquatic environment. Plant Pathol. 61:1179-1186.

Kong, P., J.D. Lea-Cox, G.W. Moorman, and C.X. Hong. 2012b. Survival of Phytophthora alni, Phytophthora kernoviae, and Phytophthora ramorum in a simulated aquatic environment at different levels of $\mathrm{pH}$. FEMS Microbiol. Lett. 332:54-60.

Kong, P., G.W. Moorman, J.D. Lea-Cox, D.S. Ross, P.A. Richardson, and C.X. Hong. 2009. Zoosporic tolerance to $\mathrm{pH}$ stress and its implications for Phytophthora species in aquatic ecosystems. Appl. Environ. Microbiol. 75:43074314.

Kong, P., P. Richardson, and C. Hong. 2017. Diversity and community structure of cyanobacteria and other microbes in recycling irrigation reservoirs. PLoS One 12(3): e0173903.

Majsztrik, J.C., A.G. Ristvey, and J.D. Lea-Cox. 2011. Water and nutrient management in the production of container-grown ornamentals. Hort. Rev. 38:253-297.

Mangiafico, S.S., J. Newman, D.J. Merhaut, J. Gan, B. Faber, and L. Wu. 2009. Nutrients and pesticides in stormwater run-off and soil water in production nurseries and citrus and avocado groves in California. HortTechnology 19:360 367.

McCarthy, M.J., P.J. Lavrentyev, L. Yang, L. Zhang, Y. Chen, B. Qin, and W.S. Gardner. 2007. Nitrogen dynamics and microbial food web structure during a summer cyanobacterial bloom in a subtropical, shallow, well-mixed, eutrophic lake (Lake Taihu, China). Hydrobiologia 581:195-207.

McEnroe, N.A., J.M. Buttle, J. Marsalek, F.R. Pick, M.A. Xenopoulos, and P.C. Frost. 2013. Thermal and chemical stratification of urban ponds: Are they 'completely mixed reactors'? Urban Ecosyst. 6:327-339.

Meador, D.P., P.R. Fisher, P.F. Harmon, N.A. Peres, M. Teplitski, and C.L. Guy. 2012. Survey of physical, chemical, and microbial 
VA22

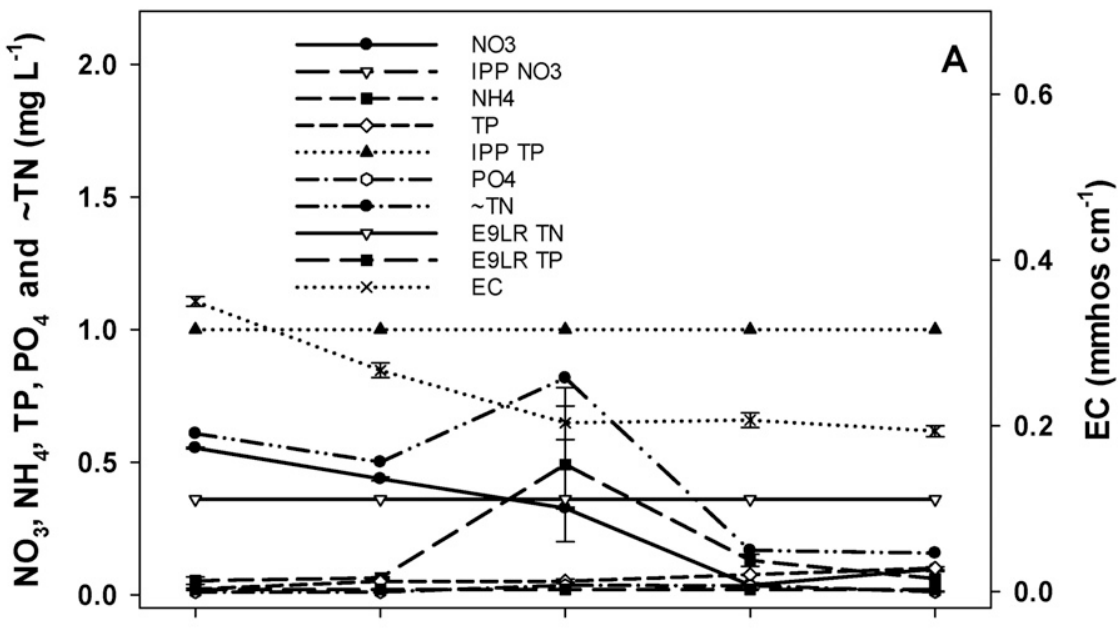

VA22

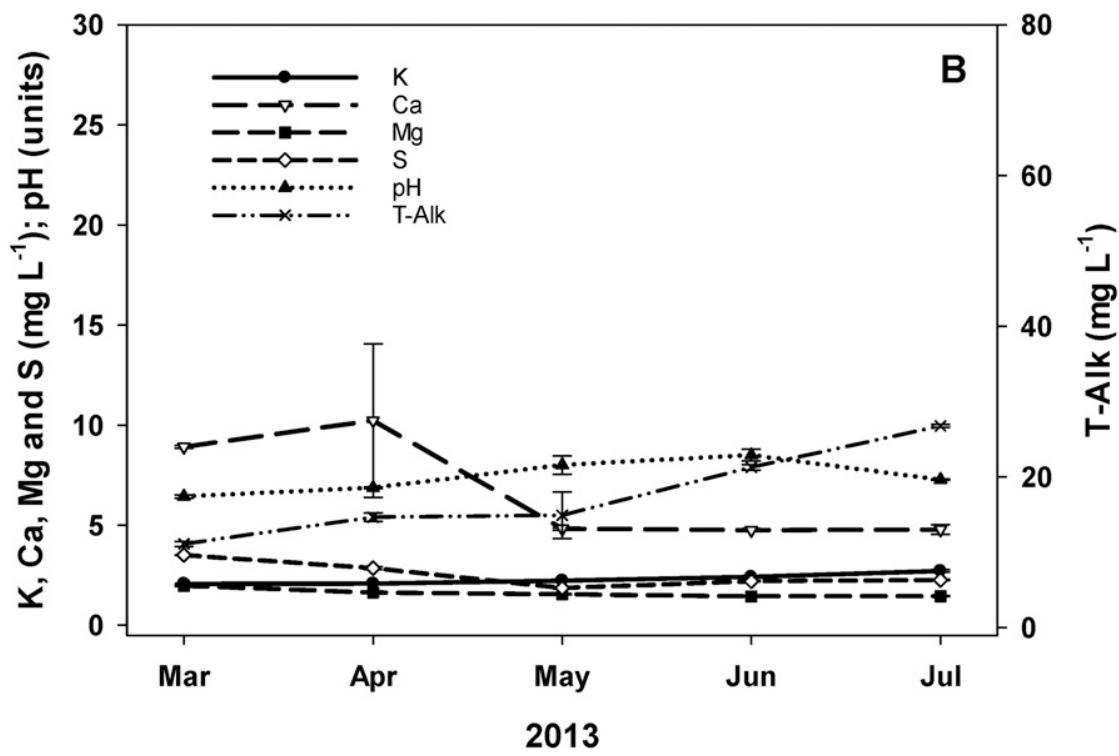

Fig. 9. Monthly mean levels $(n=5)$ of $(\mathbf{A})$ ammonium-nitrogen $\left(\mathrm{NH}_{4}{ }^{+}-\mathrm{N}\right)$, nitrate-nitrogen $\left(\mathrm{NO}_{3}{ }^{-}-\mathrm{N}\right)$, $\approx$ total-nitrogen $(\mathrm{T}-\mathrm{N})$, ortho phosphate-phosphorus $\left(\mathrm{PO}_{4}-\mathrm{P}\right)$, total-phosphorus $(\mathrm{T}-\mathrm{P})$, and electrical conductivity (EC), and the Irrigation for Plant Production Water Quality (IPP $\mathrm{NO}_{3}{ }^{-}-\mathrm{N}=10 \mathrm{mg} \cdot \mathrm{L}^{-1}$ is higher than the Y-axis range) and Ecoregion IX Lake and Reservoir Ambient Water Quality (E9LR) criteria; and of (B) potassium (K), calcium $(\mathrm{Ca})$, magnesium $(\mathrm{Mg})$, sulfur $(\mathrm{S}), \mathrm{pH}$, and total alkalinity (T-Alk) in a runoff containment basin in Virginia (VA22) in 2013.

water quality in greenhouse and nursery irrigation water. HortTechnology 22:778-786.

Moss, B., D. Stephen, C. Alvarez, E. Becares, W. van de Bund, S.E. Collings, E. van Donk, E. de Eyto, T.O. Feldmann, C. Fernández-Aláez, M. Fernández-Aláez, R.J.M. Franken, F. GracíaCriado, E.M. Gross, M. Gyllstrõm, L.A. Hansson, K. Irvine, A. Järvalt, J.P. Jensen, E. Jeppesen, T. Kairesalo, R. Kornijów, T. Krause, H.K. Uunnap, A. Laas, E. Lill, B. Lorens, H. Luup, M.R. Miracle, P. Nõges, T. Nõges, M.N. Aaneni, I. Ott, W. Peczula, E.T.H.M. Peeters, G. Phillips, S. Romo, V. Russell, J. Salujõe, M. Scheffer, K. Siewertsen, H. Smal, C. Tesch, H. Timm, L. Tuvikene, I. Tonno, T. Virro, E. Vicente, and D. Wilson. 2003. The determination of ecological status in shallow lakes-A tested system (ECOFRAME) for implementation of the European Water Framework Directive. Aquat. Conserv. Marsh and Freshwater Ecosyst. 13:507-549.
Myers, R.L. 2015. Treatment of agricultural stormwater run-off by a cascading system of floodway stormwater containment basins. University of Maryland, Doctoral Diss.

Naselli-Flores, L. and R. Barone. 2000. Phytoplankton dynamics and structure: A comparative analysis in natural and man-made water bodies of different trophic state. Hydrobiologia 438:65-74.

Obreza, T., M. Clark, B. Boman, M. Cohen, T. Frazer, E. Hanlon, K. Havens, C. Martinez, K. Migliaccio, S. Shukla, and A. Wright. 2011. A guide to EPA's numeric nutrient water quality criteria for Florida. Florida Coop. Ext. Serv. Bul. SL316.

Ouyang, Y., P. Nkedi-Kizza, Q.T. Wu, D. Shinde, and C.H. Huang. 2006. Assessment of seasonal variations in surface water quality. Water Res. 40:3800-3810.

Pershey, N.A., B.M. Cregg, J.A. Andresen, and R.T. Fernandez. 2015. Irrigating based on daily water use reduces nursery run-off volume and nutrient load without reducing growth of four conifers. HortScience 50:1553-1561.

Piñol, J., A. Ávila, and F. Rodà. 1992. The seasonal variation of stream water chemistry in three forested Mediterranean catchments. J. Hydrol. (Amst.) 140:119-141.

Robbins, J. 2010. Irrigation water for greenhouses and nurseries. Univ. Arkansas Coop. Ext. Ser. Agr. Natl. Resources Bul. FSA6061-PD-5-10RV.

Scheffer, M. and E.H. van Nes. 2007. Shallow lakes theory revisited: Various alternative regimes driven by climate, nutrients, depth and lake size. Hydrobiologia 584:455-466.

Song, K., M.A. Xenopoulos, J.M. Buttle, J. Marsalek, N.D. Wagner, F.R. Pick, and P.C. Frost. 2013. Thermal stratification patterns in urban RCBs and their relationships with vertical nutrient gradients. J. Environ. Mgt. 127:317-323.

Steegen, A., G. Govers, I. Takken, J. Nachtergaele, J. Poesen, and R. Merckx. 2001. Factors controlling sediment and phosphorus export from two Belgian agricultural catchments. J. Environ. Qual. 30:1249-1258.

Steele, M.K., W.H. McDowell, and J.A. AitkenheadPeterson. 2010. Chapter 15: Chemistry of urban, suburban, and rural surface waters, p. 297-339. In: J.A. Aitkenhead-Peterson and A. Volder (eds.). Urban Ecosystem Ecology. Agronomy Monograph 55. Agronomy Society of America, Madison, WI.

Stutter, M.I., S.J. Langan, and R.J. Cooper. 2008. Spatial and temporal dynamics of stream water particulate and dissolved $\mathrm{N}, \mathrm{P}$ and $\mathrm{C}$ forms along a catchment transect, NE Scotland. J. Hydrol. (Amst.) 350:187-202.

USEPA. 2000. Ambient water quality criteria recommendations. Information supporting the development of state and tribal nutrient criteria for lakes and reservoirs in nutrient ecoregion IX. EPA-822-B-00-011.

USEPA. 2001. Ambient water quality criteria recommendations. Information supporting the development of state and tribal nutrient criteria for lakes and reservoirs in nutrient ecoregion XIV. EPA-822-B-01-011.

USEPA. 2014. Water quality standards handbook. 3 Jan. 2017. <https://www.epa.gov/wqs-tech/ water-quality-standards-handbook $>$.

Valdez-Aguilar, L.A., C.M. Grieve, J. Poss, and M.A. Mellano. 2009. Hypersensitivity of $R a$ nunculus asiaticus to salinity and alkaline $\mathrm{pH}$ in irrigation water in sand cultures. HortScience 44:138-144.

Wang, L., Q. Cai, L. Tan, and L. Kong. 2011. Phytoplankton development and ecological status during a cyanobacterial bloom in a tributary bay of the Three Gorges Reservoir, China. Sci. Total Environ. 409:3820-3828.

Warsaw, A.L., R.T. Fernandez, B.M. Cregg, and J.A. Andresen. 2009a. Container-grown ornamental plant growth and water run-off nutrient content and volume under four irrigation treatments. HortScience 44:1573-1580.

Warsaw, A.L., R.T. Fernandez, B.M. Cregg, and J.A. Andresen. 2009b. Water conservation, growth, and water use efficiency of containergrown woody ornamentals irrigated based on daily water use. HortScience 44:1-11.

Wilson, C., J. Albano, M. Mozdzen, and C. Riiska. 2010. Irrigation water and nitrate-nitrogen loss characterization in southern Florida nurseries: Cumulative volumes, run-off rates, nitratenitrogen concentrations and loadings, and implications for management. HortTechnology 20:325-330.

Yang, X., Q. Liu, G. Fu, Y. He, X. Luo, and Z. Zheng. 2016. Spatiotemporal patterns and 
VA23

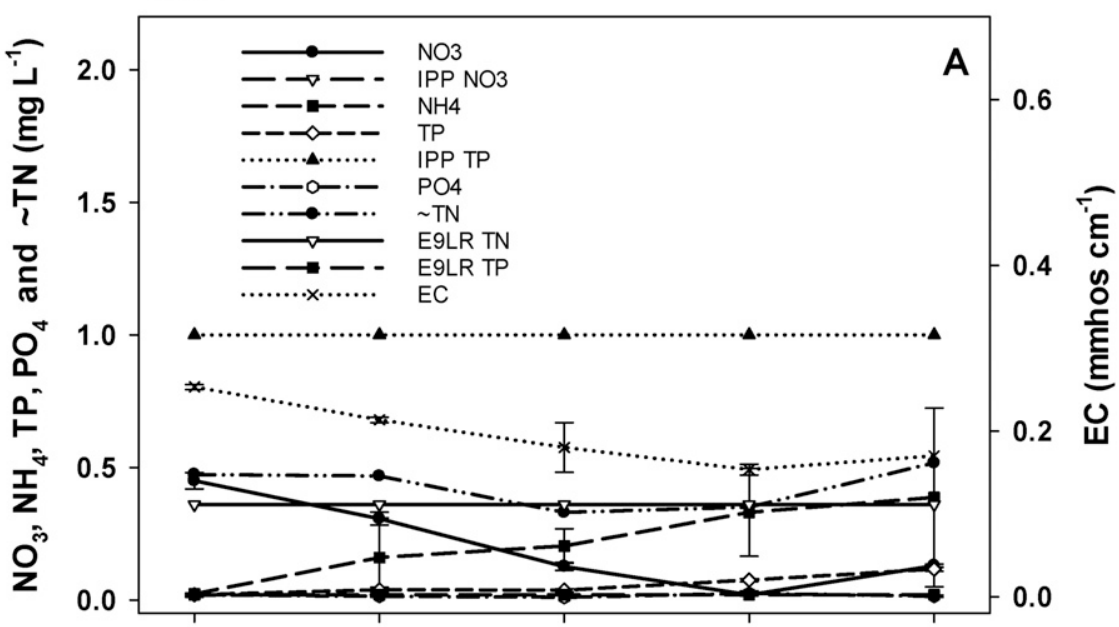

VA23

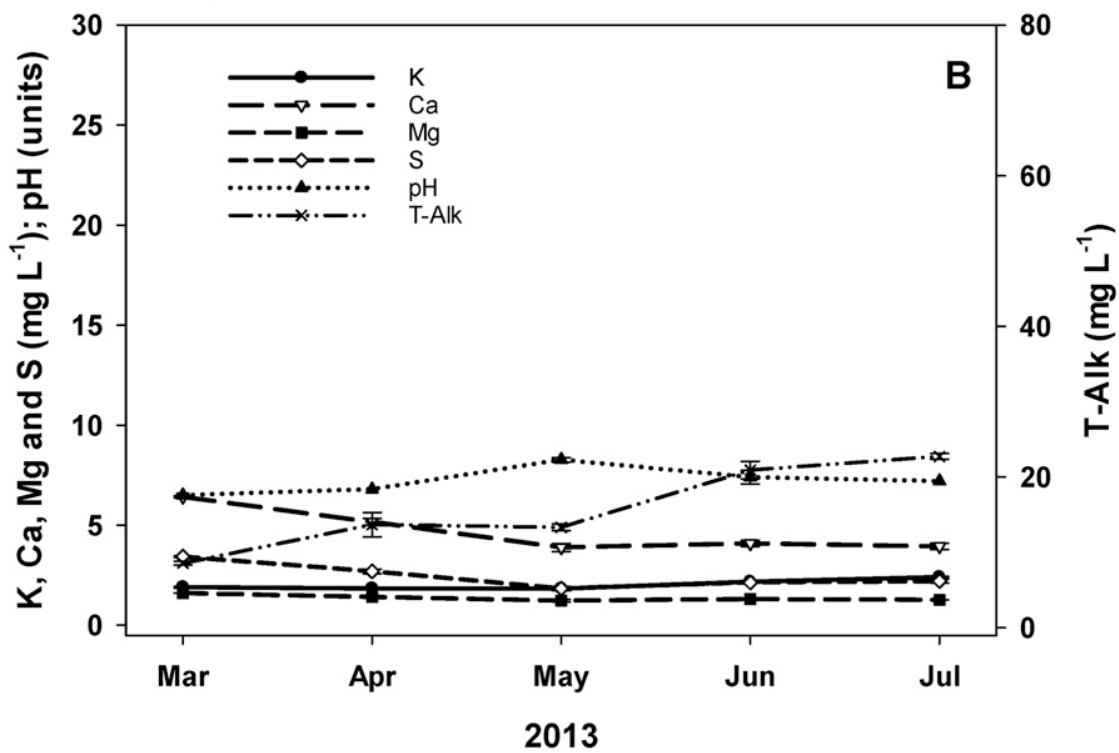

Fig. 10. Monthly mean levels $(n=5)$ of $(\mathbf{A})$ ammonium-nitrogen $\left(\mathrm{NH}_{4}{ }^{+}-\mathrm{N}\right)$, nitrate-nitrogen $\left(\mathrm{NO}_{3}{ }^{-}-\mathrm{N}\right)$, $\approx$ total-nitrogen $(\mathrm{T}-\mathrm{N})$, ortho phosphate-phosphorus $\left(\mathrm{PO}_{4}-\mathrm{P}\right)$, total-phosphorus (T-P) and electrical conductivity (EC), and the Irrigation for Plant Production Water Quality (IPP $\mathrm{NO}_{3}{ }^{-} \mathrm{N}=10 \mathrm{mg} \cdot \mathrm{L}^{-1}$ is higher than the Y-axis range) and Ecoregion IX Lake and Reservoir Ambient Water Quality (E9LR) criteria; and of (B) potassium (K), calcium $(\mathrm{Ca})$, magnesium $(\mathrm{Mg})$, sulfur $(\mathrm{S}), \mathrm{pH}$, and total alkalinity (T-Alk) in a runoff containment basin in Virginia (VA23) in 2013. source attribution of nitrogen load in a river basin with complex pollution sources. Water Res. 94:187-199.

Yang, X.E., X. Wu, H.L. Hao, and Z.L. He. 2008. Mechanisms and assessment of water eutrophication. J. Zhejiang Univ. Sci. B 9:197-209.

Yeager, T. and G. Cashion. 1993. Controlledrelease fertilizers affect nitrate nitrogen runoff from container plants. HortTechnology 3:174-177.

Yeager, T., R. Wright, D. Fare, C. Gilliam, J. Johnson, T. Bilderback, and R. Zondag. 1993. Six state survey of container nursery nitrate nitrogen run-off. J. Environ. Hort. 11:206-208.

Zhang, H., P.A. Richardson, B.E. Belayneh, A Ristvey, J. Lea-Cox, W.E. Copes, G.W. Moorman, and C. Hong. 2015a. Characterization of water quality in stratified nursery recycling irrigation reservoirs. Agr. Water Mgt. 160:7683.

Zhang, H., P.A. Richardson, B.E. Belayneh, A. Ristvey, J. Lea-Cox, W.E. Copes, G.W. Moorman, and C. Hong. 2015b. Comparative analysis of water quality between run-off entrance and middle of recycling irrigation reservoirs. Water 7:3861-3877.

Zhang, H., P.A. Richardson, B.E. Belayneh, A Ristvey, J. Lea-Cox, W.E. Copes, G.W. Moorman, and C. Hong. 2016. Recycling irrigation reservoir stratification and implications for crop health and production. J. Amer. Water Resources Assn. 52:620631.

Zhu, G., B. Quin, G. Gao, L. Zhang, L. Luo, and Y. Zhang. 2007. Effects of hydrodynamics on phosphorus concentrations in water of Lake Taihu, a large, shallow, eutrophic lake in China. Hydrobiologia 581:53-61.

Zhu, W., L. Wan, and L. Zhao. 2010. Effect of nutrient level on phytoplankton community structure in different water bodies. J. Environ. Sci. (China) 22:32-39. 